\title{
Microphytobenthic primary production in the Bodden estuaries, southern Baltic Sea, at two study sites differing in trophic status
}

\author{
Sabine Ulrike Gerbersdorf ${ }^{1,2, *}$, Jürgen Meyercordt ${ }^{1}$, Lutz-Arend Meyer-Reil ${ }^{1}$ \\ ${ }^{1}$ Institut für Ökologie, Ernst-Moritz-Arndt-Universität Greifswald, Schwedenhagen 6, 18565 Kloster/Hiddensee, Germany \\ ${ }^{2}$ Present address: Institut für Wasserbau, Versuchsanstalt, Pfaffenwaldring 61, Universität Stuttgart, 70550 Stuttgart, Germany
}

\begin{abstract}
Eutrophication in coastal areas has stimulated phytoplankton growth, sustaining a high biomass and leading to a shift in the underwater light field. With the significance of the microphytobenthos for oxygen supply and carbon budget of both benthic and pelagic habitats in mind, the possible effects of reduced light availability were investigated in the estuarine Bodden area (southern Baltic Sea) at 2 sites differing in trophic status - the eutrophic Kirr Bucht (KB) and the mesotrophic Rassower Strom (RS). Using for the first time microsensors in Bodden sediments, it was possible to visualize small-scale heterogeneity in the light regime, photosynthetic activity and oxygen penetration with high spatial and temporal resolution. Hence, differences at the 2 sites related to sediment characteristics (KB sandy, RS muddy), and photoautotrophic biomass (benthic chlorophyll $a$ in the upper $1 \mathrm{~cm}, \mu \mathrm{g} \mathrm{cm}{ }^{-3}=11$ to 48 at $\mathrm{KB}$ and 13 to 17 at RS) could be ruled out. Calculations of benthic primary production based solely on microelectrode measurements revealed substantial oxygen fluxes and carbon fixation rates at in situ light intensities at both study sites (e.g. gross primary production, GPP, mg $\mathrm{C} \mathrm{m}^{-2} \mathrm{~h}^{-1}=28$ to 80 at $\mathrm{KB}$ and 3 to 36 at RS). The different combinations of water transparency (pelagic chlorophyll $a$, $\mu \mathrm{g} \mathrm{l}^{-1}=12$ to 33 at $\mathrm{KB}$ and 1.3 to 4.5 at $\left.\mathrm{RS}\right)$, light attenuation $k\left(3.17 \mathrm{~m}^{-1}\right.$ at $\mathrm{KB}, 0.61 \mathrm{~m}^{-1}$ at $\mathrm{RS})$ and water depth (0.6 $\mathrm{m}$ at $\mathrm{KB}, 3.4 \mathrm{~m}$ at RA) have led to a similar light availability for benthic algae on the sediment surface at both study sites. Consequently, the benthic algae had comparable

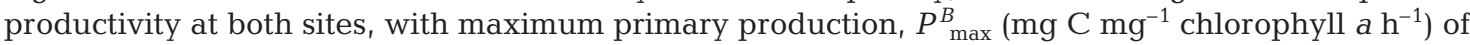
0.29 to 1.46 at $\mathrm{KB}$ and 0.17 to 1.63 at RS; and were adapted to rather low light conditions, with light saturation, $E_{k}\left(\mu \mathrm{E} \mathrm{m}^{-2} \mathrm{~s}^{-1}\right)$ of 22 to 152 at $\mathrm{KB}$ and 10 to 116 at RS). Varying with season, microphytobenthic photosynthetic activity accounted for 26 to 59 and 2 to $53 \%$ to the total primary production at the $\mathrm{KB}$ and RS, respectively, with the highest contribution in spring coincident with the most favourable light conditions at the sediment surface. With an annual average of about 37 and $30 \%$ (KB and RS, respectively), the contribution of the microphytobenthos to total production was significant and comparable at both study sites. Nevertheless, the higher trophic status at KB resulted in a change in the benthic microalgal community towards sedimentated phytoplankton species and had a negative impact on microphytobenthic primary production rates. This was estimated by calculating the gross primary production for varying water depths on the basis of the different water transparency at the 2 sites.
\end{abstract}

KEY WORDS: Microphytobenthos $\cdot$ Primary production $\cdot$ Microsensors $\cdot$ Microprofiles $\cdot$ Phytoplankton Benthic-pelagic coupling $\cdot$ Estuary $\cdot$ Baltic Sea

Resale or republication not permitted without written consent of the publisher

\section{INTRODUCTION}

In shallow non-tidal waters, the light climate allows the development of a photoautotrophic benthic community (Wasmund 1986, Miller et al. 1996). The micro- phytobenthos is presumed to be important in stabilising sediments (de Brouwer et al. 2003) and in controlling nutrient fluxes directly at the sediment/water interface through nutrient uptake (Sundbäck et al. 1991, Rizzo et al. 1992, Wiltshire 1992). Moreover, 
oxygenation of the sediment surface layers by photosynthetic activity leads to indirect geochemical fixation of nutrients and heavy metals (Koop et al. 1990, Nielsen et al. 1990). Furthermore, the supply of oxygen through photosynthetic activity determines the occurrence of heterotrophic organisms such as protozoans and meiofauna in the upper sediment (Berninger \& Epstein 1995). In terms of primary production, the microphytobenthic community may account for the main part of carbon fixation, especially in shallow waters (Cadee \& Hegeman 1974, Plante-Cuny \& Bodoy 1987, MacIntyre \& Cullen 1996, MacIntyre et al. 1996, Underwood et al. 2004).

During the last few decades, phytoplankton growth has been stimulated in many coastal zones by an increased supply of nutrients, which sustains a high biomass and has led to a shift in the underwater light climate (Radach et al. 1990, Schiewer 1998). Several publications have dealt with the pelagic primary production in the Bodden estuaries (estuarine areas in the Southern Baltic Sea, hereafter referred to as 'the Bodden') (Hübel 1968, Börner \& Kell 1982). These publications have clearly documented increased phytoplankton biomass and primary production rates related to change in the trophic status over the last $30 \mathrm{yr}$ (Wasmund 1990, Wasmund \& Schiewer 1994, Bachor et al. 1996, Hübel et al. 1998). Increased phytoplankton abundance has led to a reduction in light penetration and hence a decline in macrophytes and submerged flowering plants (Behrens 1982, Teubner 1989). The change in the underwater light climate may also significantly affect the microphytobenthic primary production, as light intensity is considered to be the primary factor controlling benthic photosynthesis (Colijn 1982, Pickney \& Zingmark 1993). Despite the significance of the microphytobenthos, comparatively little data has been published on microphytobenthic primary production and the possible effects of eutrophication, globally and for the sublittoral in particular. For the Bodden, only a few studies have focused on the microphytobenthic community and primary production rates (Täuscher 1976, Krause 1977, Wasmund 1986). To date, almost nothing has been recorded on the present status of microphytobenthos in the Bodden in general and the possible effects of light limitation on microphytobenthic production and community dynamics in particular. Only recently has data on the primary production rates of benthic microalgae and their contribution to the total primary production of the shallow Bodden as a function of trophic status been reported (Gerbersdorf \& Meyercordt 1999, Gerbersdorf et al. 2000). The photoautotrophic character of the flocculent sediment surface layer, its fractions and its aggregates indicated the significance of the microphytobenthos in the Bodden for the oxygen/carbon budget of the benthic habi- tat and its role as an important link in benthic-pelagic coupling after resuspension events (Gerbersdorf et al. 2004).

Herein, we report the first comprehensive investigations on microphytobenthos over a seasonal range to be carried out in the Bodden estuaries at 2 study sites differing in trophic status. In contrast to recent publications (Meyercordt \& Meyer-Reil 1999, Meyercordt et al. 1999), microphytobenthic primary production rates in the present study were determined solely by microelectrodes. Moreover, interpolation of the data for the time intervals between measurements was done using the Walsby (1997) model. Especially in the low light range, microelectrode measurements are far more sensitive than other integrative methods, and allow the direct determination of gross photosynthesis rates within the sediment (Revsbech et al. 1981, Revsbech \& Jørgensen 1983, Sommer 1994, Karsten \& Kühl 1996, Gerbersdorf 2000). Thus, the measurements of benthic production rates are more reliable, and hence calculations on the sediment oxygen budget and carbon supply to the benthic habitat as well as to the pelagic habitat after resuspension are more precise. Moreover, microprofiles of light and oxygen reveal mutual changes in abiotic factors and the resulting microphytobenthic photosynthetic activity at high spatial and temporal resolution, which can only be detected as a sum otherwise (Revsbech \& Jørgensen 1986, Lassen et al. 1992). The Walsby (1997) model takes the reflection characteristics of the light at the water surface under different solar angles into consideration. Hence the calculations of the underwater light field and corresponding production rates (especially with regard to the different trophic status of the 2 study sites) achieved further precision in the present study. Possible physiological adaptations of the benthic algae to prevailing light conditions were examined using photosynthesis/irradiance $(P / E)$ curves with data on maximum photosynthetic capacity $\left(P_{\max }\right)$, photosynthetic efficiency $(\alpha)$ and the light saturation coefficent $\left(E_{k}\right)$ (Kohl \& Nicklisch 1988, Pickney \& Zingmark 1991, Falkowski \& Raven 1997, Barranguet et al. 1998). To examine possible effects of eutrophication on the benthic microalgal community (Sundbäck \& Snoeijs 1991), the species composition of the phytoplankton and microphytobenthos was determined microscopically at the 2 study sites.

\section{MATERIALS AND METHODS}

Study sites. Two study sites in the estuarine Bodden area, southern Baltic Sea (Fig. 1) differing in morphometry, hydrography and trophic status, were investigated at different seasons. The Kirr-Bucht (KB) is an 


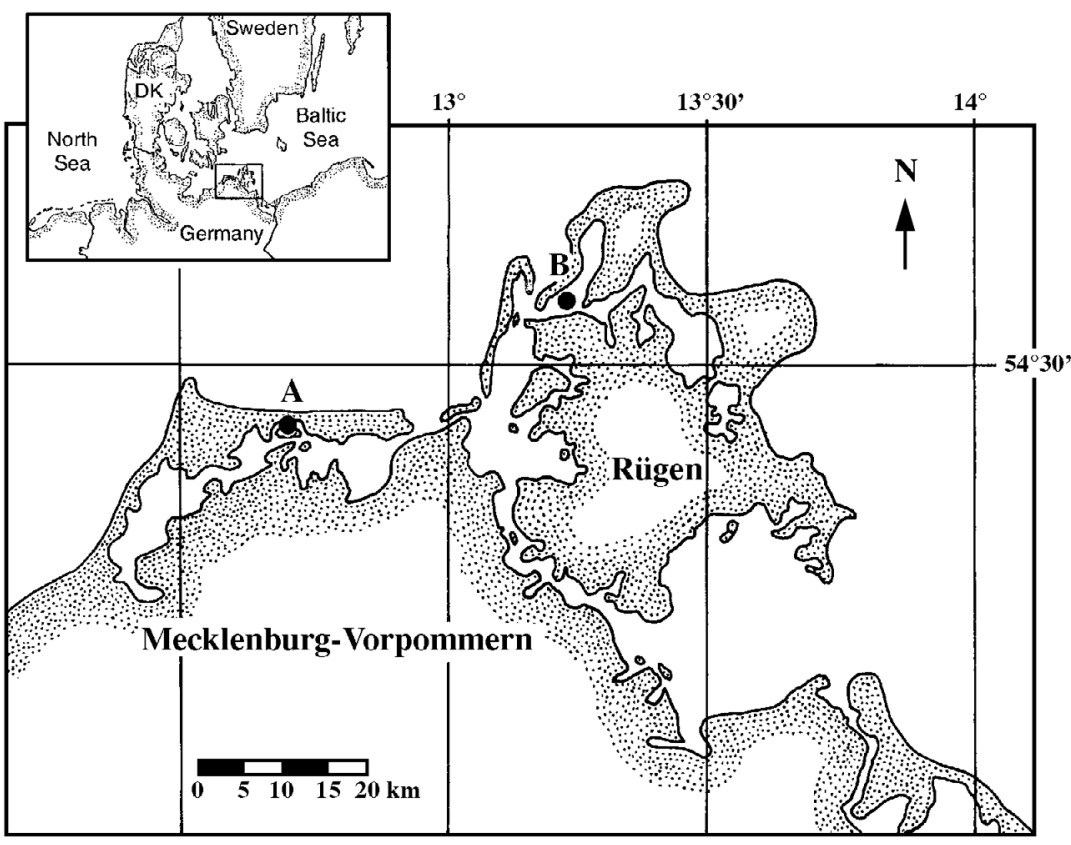

Fig. 1. Study sites. A: Kirr Bucht (inner part of the Darss-Zingster Boddenkette); B: Rassower Strom (outer part of the Nordrügensche Boddenkette), both located in the estuarine Bodden area of the southern Baltic Sea. DK: Denmark
Sampling and treatment. Sampling took place once each season (July 1996, September/October 1996, January 1997, April 1997) at each study site. For benthic primary production measurements, undisturbed sediment cores of about $100 \mathrm{~mm}$ length and $1.1 \mathrm{l}$ of overlying ambient water were taken using cylindrical Plexiglas tubes (length $300 \mathrm{~mm}$, internal diameter $100 \mathrm{~mm}$ ) either with a hand-manipulated coring device or with a multicorer device (Barnett et al. 1984) at Sites KB and RS, respectively (the device used depended on the shallowness of the investigation area). The sediment cores were carefully transported to the laboratory and placed in a room protected from electrical 'noise'. Sediment cores were placed into a water bath and the in situ temperature was kept constant by a cooling system. During photosynthesis measurements, the sediment cores were illuminated under different light intensities by a halogen cold light source (Schott, KL 1500 electronic), with the lamp at a $45^{\circ}$ angle to avoid shading by the microsensor. The exposure of the inner area in the Darss-Zingster Boddenkette, characterised by low salinities (5.0 to 6.6) and high nutrient concentrations (Gerbersdorf et al. 2004, S. Dahlke pers. comm.). Its high chlorophyll a concentrations (12 to $33 \mu \mathrm{g} \mathrm{l}^{-1}$ ) and pelagic primary production rates (Hübel et al. 1998) are typical for eutrophic waters (Wasmund $\&$ Kell 1991). In a water depth of $0.6 \mathrm{~m}$, the sediment is sandy with an organic carbon content of $1 \%$. Rassower Strom (RS) is one of the outer Bodden estuaries of the Nord-Rügensche Boddenkette, and consequently is more strongly influenced by the Baltic Sea, having higher salinities (8.2 to 9.4) and low nutrient concentrations (Gerbersdorf et al. 2004, S. Dahlke pers. comm.). Because of its lower chlorophyll a concentrations (1.3 to $4.5 \mu \mathrm{g} \mathrm{l}^{-1}$ ) and pelagic primary production rates (Hübel et al. 1998), this study site is regarded as mesotrophic (Wasmund \& Kell 1991). The sediment in approximately $4 \mathrm{~m}$ water depth consists of sandy mud with an organic carbon content of up to $4 \%$ on its surface. In January 1997, the RS was not accessible due to ice cover. Therefore, another nearby sampling station, the Klosterloch, which is comparable to the RS in terms of water and sediment characteristics, was used for this month. (For simplicity, the term 'Rassower Strom, RS', will be used hereafter for data from Klosterloch and RS.) More details on the morphology and hydrography of KB and RS are available in Correns \& Jäger (1979, 1982), Schlungbaum et al. (1994), Meyercordt et al. (1999) and Gerbersdorf et al. (2004). samples to different irradiances (ranging from in situ to artificial high light intensities) was alternated by dark periods. The water column above the sediment was aerated to keep the oxygen concentration constant. To measure pelagic primary production and respiration, water samples were incubated in situ in 3 sets of 4 transparent and 4 black bottles over a period of about $10 \mathrm{~h}$. Each set of bottles was exposed at a different water depth (below surface, above bottom and mid water; for further details see Meyercordt et al. 1999).

Natural light intensities at sediment surface. Natural in situ light intensities experienced by the microphytobenthos were calculated for each season for both sites (Table 1). The light attenuation coefficient $(k)$ in the water column was calculated from vertical light intensity profiles in decimetre to metre steps by a spherical underwater sensor (LI-COR LI 193SA). In combination with data on photosynthetically active radiation (PAR, 400 to $700 \mathrm{~nm}$ ), which was continuously measured above the water surface (LI-COR LI 190SA), $k$ values were used to calculate the lowest, medium and highest irradiances at the sediment surface for the relevant periods (Table 1).

Chlorophyll $\boldsymbol{a}$ and phaeopigment $\boldsymbol{a}$. Pigments in water samples of a defined volume were concentrated on Whatman GF/C filters, which were immediately deep-frozen. The sediment cores were sectioned into different layers at intervals of $1 \mathrm{~cm}$ and each layer was mixed thoroughly to avoid patchiness in the pigment 
Table 1. Light attenuation $k\left(\mathrm{~m}^{-1}\right)$ in the water column and range of in situ light intensities (lowest to highest) available to the microphytobenthos at the sediment surface in the Kirr Bucht and Rassower Strom (Bodden area of the southern Baltic Sea). Irradiance calculated on an hourly basis from constantly measured photosynthetically active radiation above the water surface and light attenuation in the water column, averaged for relevant month

\begin{tabular}{|lccrr|}
\hline \multirow{2}{*}{ Month } & \multirow{2}{*}{$k$} & \multicolumn{4}{c|}{ Light intensity $\left(\mu \mathrm{E} \mathrm{m}^{-2} \mathrm{~s}^{-1}\right)$} \\
& & Low & Medium & High \\
\hline Kirr Bucht & & & & \\
July 1996 & 3.48 & 75 & 180 & 300 \\
October 1996 & 3.31 & 26 & 153 & 222 \\
January 1997 & 2.17 & 10 & 41 & 97 \\
April 1997 & 3.73 & 18 & 98 & 168 \\
Rassower Strom & & & & \\
July 1996 & 0.57 & 45 & 117 & 180 \\
October 1996 & 0.73 & 12 & 80 & 120 \\
January 1997 & 0.56 & 20 & 35 & 100 \\
April 1997 & 0.59 & 19 & 107 & 177 \\
\hline
\end{tabular}

concentrations. From each sediment layer, 5 subsamples of $0.5 \mathrm{~cm}^{3}$ each were taken with a cut-off syringe and stored deep frozen in centrifuge tubes. Pigment analysis following the guidelines of the Helsinki Commission (HELCOM 1988). Pigments were extracted in $96 \%$ ethanol followed by spectrophotometric readings at $665 \mathrm{~nm}$ before and after acidification with $\mathrm{HCl}$ to correct for the phaeopigment a concentrations (PerkinElmer UV/VIS spectrometer lambda 2).

Light and oxygen fluxes. On the assumption that oxygenic photosynthesis is the main pathway of carbon dioxide fixation in the Bodden, changes in oxygen concentrations were recorded in the water samples and sediment to calculate pelagic and benthic photosynthesis, respectively. The terms photosynthesis and primary production are interchangeable in the following text.

Oxygen exchange: Since oxygen fluxes can be derived from microelectrode profiles only in sediments, the pelagic primary production and respiration was measured in situ by changes in the oxygen concentration in water samples under light and dark conditions, determined by the Winkler method. The light conditions for the incubated water samples were recorded via a spherical underwater sensor (LI-COR LI 193SA; for further details see Meyercordt et al. 1999.)

Microelectrode measurements: Microsensors were used to determine the light intensity, light attenuation and the photic zone $\left(z_{\mathrm{PAR}}\right)$, as well as the oxygen concentration and penetration depth $\left(z_{\text {oxygen }}\right)$ in the upper sediment layers in relation to illumination at the sediment surface. The microsensors enabled measurements of high vertical (50 to $100 \mu \mathrm{m})$ and temporal $(<0.1 \mathrm{~s})$ resolution. The Clark-type oxygen microelectrodes were built according to Revsbech \& Jørgensen (1986) and the light sensors were modified after Lassen et al. (1992). The precise position of the microsensors was observed through a dissection microscope, using a micromanipulator with a control unit (Märzhäuser \& Wetzlar, Type DC 3-K right and MS314) for positioning.

The microsensors determine oxygen gradients at the sediment/water interface, caused by photosynthetic and heterotrophic activity, under dark and light conditions. The resulting oxygen fluxes (upwards out of the sediment into the water column and downwards into deeper sediment horizons) have been used to calculate oxygen consumption/production (Revsbech et al. 1981, Sommer 1994). For these calculations, the diffusion coefficient of oxygen in the water and sediments as well as the porosity of the sediment must be taken into account (Li \& Gregory 1974, Ullmann \& Aller 1982, Revsbech \& Jørgensen 1986, Rasmussen \& Jørgensen 1992). Oxygen microelectrodes can also be used to directly determine gross photosynthesis by the light/ dark shift method (Revsbech et al. 1981, Revsbech \& Jørgensen 1983, 1986). Thereby a steady state of oxygen distribution will be achieved under constant conditions and the initial decrease in oxygen within $1 \mathrm{~s}$ after darkening the sediment reflects gross photosynthesis (Revsbech \& Jørgensen 1983, Karsten \& Kühl 1996). This is the only method that takes into account variation in oxygen consumption in darkness and at different irradiances arising from differential expansion of the oxic layer and/or changes in volumetric respiration rates in response to oxygen supply (Epping 1996). To avoid changes in oxygen concentration due to osmotic effects, the vertical spatial resolution of the light/dark shift method is restricted to layers of approximately $100 \mu \mathrm{m}$ by the oxygen diffusion velocity, which is $67 \mu \mathrm{m} \mathrm{s}^{-1}$ according to the Einstein-Smoluchowski law (Neudörfer \& Meyer-Reil 1998).

Microscale variations in the occurrence of benthic organisms and their metabolic activities are well documented (Revsbech et al. 1983, Jørgensen \& Revsbech 1985, review by Meyer-Reil 1994) and may hamper the extrapolation of rates measured by microelectrodes. Therefore, to obtain a representative overview of respiration and photosynthetic activity in the sediments, 6 to 12 vertical profiles were taken randomly from the sediment surface of each sediment core.

Primary production. Pelagic gross photosynthesis was calculated as the sum of respiration and net photosynthesis. Microphytobenthic photosynthetic activity was determined similarly, but also directly by the light/dark shift method, whereby the gross photosynthesis rates for the different sediment layers were related to volume and multiplied by the vertical expansion $\left(z_{\mathrm{phot}}\right)$ of the measured profile of photosynthetic activity (Revsbech et al. 1981, Revsbech \& Jørgensen 1983, 1986). 
Gross primary production rates were expressed as C-equivalents using the conversion factor 1.2 (Mills \& Wilkinson 1986) and taking main substrates and products of dioxide fixation into account (Burris 1981, Raine 1983, Sakshaug et al. 1997). Gross primary production rates of pelagic and microphytobenthic area were normalised to chlorophyll a concentrations in the water samples and in the flocculent sediment surface layer, respectively, to correct for algal biomass. The different resolution of sediment pigment profiles (0.5 cm steps in the upper layers) and oxygen/gross photosynthesis microprofiles $(100 \mu \mathrm{m})$ did not allow appropriate algal biomass correction, and represents a challenge for further experiments.

Photosynthesis models. In a literature overview, Jassby \& Platt (1976) discussed different photosynthesis models that have been used to mathematically describe oxygen production rates as a function of light conditions (photosynthesis vs. irradiance, $P / E$, curves). We tested 4 models to describe the experimental data:

$$
\begin{aligned}
P^{B} & =P_{\max } \alpha E /\left(P_{\max }+\alpha E\right) & & \text { Baly (1935) } \\
P^{B}= & P_{\max } \tanh \left(\alpha E / P_{\max }\right) & & \text { Jassby \& Platt (1976) } \\
P^{B}= & P_{\max }\left[1-\exp \left(-\alpha E / P_{\max }\right)\right] & & \text { Webb et al. (1974) } \\
P^{B}= & P_{\max }\left[1-\exp \left(-\alpha E / P_{\max }\right)\right] & & \text { Walsby (1997) } \\
& +(E \beta)+R & &
\end{aligned}
$$

where $P^{B}$ represents production rate at a given illumination, $E_{;} P_{\text {max }}$ is maximum gross primary production rate under optimal light conditions (= photosynthetic capacity); $\alpha$ is photosynthetic efficiency in the lightlimited part of the $P / E$ curve; the $P_{\max }: \alpha$ ratio yields $E_{k}$, which is an indicator of photosynthetic adaptation to prevailing light conditions; $\beta$ is photoinhibition under high light intensities; and $R$ is respiration. Normalised to chlorophyll a concentrations, the terms $P^{B}{ }_{\max }$ and $\alpha^{B}$ will be used forthwith instead of the area-related terms $P_{\max }$ and $\alpha$.

Adaptation of the models to the experimental data was estimated by differences in the data obtained from the fitted curve. The total error (sum of squared differences between the measured data and the fitted curve) depends strongly on the absolute values of the photosynthetic rates. Thus, the total error was divided by the sum of the gross primary production rates of the fitted curve. In this way, the degree of adaptation of the different models to the experimental data was obtained for the different seasons and both study sites (data not shown). The photosynthesis model of Webb et al. (1974) best described the experimental data.

Modelling. An interpolation of the data for times between experiments was achieved by applying $P / E$ parameters and measured respiration rates to the photosynthesis model of Walsby (1997) with the aid of constantly measured PAR data. Walsby's (1997) model considers not only PAR attenuation within the water body, but also the reflection characteristics of the water surface. Therefore, calculations of light availability for phytoplankton in different water depths as well as for microphytobenthos at the sediment surface gained further precision. Using these light field calculations, pelagic primary production was calculated in $0.1 \mathrm{~m}$ steps from the water surface down to the bottom, and integrated over the whole water column on an hourly basis. Benthic primary production and respiration were also calculated on an hourly basis using the calculated PAR values at the sediment surface.

Statistics. The assumptions of normality and homogeneity of variance were tested using visual assessment of the frequency histogram and normal plot, as well as skewness and kurtosis, both of which provide information on the symmetry and peakiness of a distribution (Armitage \& Berry 1994). Additionally, the Shapiro-Wilk $W$-test indicated normal distribution of the data ('Analyse-it' for Microsoft Excel). Hence, a 2-way ANOVA was applied to test for differences between the means of samples classified by the categories of 2 factors (study site and season) ('Analyse-it' for Microsoft Excel). The model tested for the main effects of study site and season, as well as interactions between study site and season. When significant $(\mathrm{p}<$ 0.05) effects were detected, an a posteriori comparison were made using Tukey's test ('Analyse-it' for Microsoft Excel; Armitage \& Berry 1994, Lozán \& Kausch 1998).

\section{RESULTS}

\section{Species composition}

For the eutrophic Kirr Bucht (KB), microscopic studies revealed a phytoplankton community typical for inner Bodden estuaries, with high diversity and little seasonal variation. The following were the most commonly found species (Pankow 1990, Lange-Bertalot 1998): Aphanocapsa sp., Aphanothece clathrata, Gomphosphaeria lacustris, G. pusilla, Merismopedia glauca, M. punctata, Microcystis aeruginosa and M. botrys (Cyanophyceae: Chroococcales); Anabaena torulosa, A. spiroides, Lyngbya contorta and Oscillatoria tenuis (Cyanophyceae: Nostocales); Skeletonema costatum (Bacillariophyceae: Centrales); Diatoma vulgare and Surirella ovalis (Bacillariophyceae: Pennales); Botryococcus braunii, Kirchneriella lunaris, Monoraphidium contortum, Oocystis pelagica, Pediastrum boryanum, Scenedesmus sp. (7 species) and Tetrastrum triangulare (Chlorophyceae: Chlorococcales).

In contrast, the phytoplankton community at the mesotrophic study site Rassower Strom (RS) resembled the species composition of the offshore region (Arkona- 
see), with seasonal successions from diatom blooms in spring to Cyanobacteria dominance in summer and Dinophyceae development in autumn. The following species were most abundant (Pankow 1990, LangeBertalot 1998): Anabaena torulosa and Oscillatoria tenuis (Cyanophyceae: Nostocales); Cyclotella comta, Chaetoceros danicus, Coscinodiscus radiatus, Melosira sp., Skeletonema costatum and Stephanodiscus sp. (Bacillariophyceae: Centrales); Gyrosigma sp., Pleurosigma sp. and Surirella sp. (Bacillariophyceae: Pennales); Dinophysis sp., Gymnodinium sp., Peridinium granii, Prorocentrum minimum and P. balticum (Dinophyceae); Oocystis sp. and Pediastrum boryanum (Chlorophyceae: Chlorococcales).

In the KB, Cyanobacteria (Chroococcales) and Chlorophyceae (Chlorococcales) dominated the algal community both on and within the sediment and in the water column, from where most species originated. Benthic pennate diatom species were found in low abundances (Amphora sp., Cocconeis sp., Navicula sp., Nitzschia sp., Surirella sp.). At the RS, a true microphytobenthos was established, with a high diversity of pennate diatoms: Achnanthes delicatula, Amphora sp.,
Cocconeis scutellum, C. placentula, Cymbella affinis, Diploneis didyma, D. smithii, Epithemia turgida, Fragilaria sp., Navicula pygmaea, $N$. digitoradiata, Nitzschia compressa, N. constricta, Opephora sp., Pleurosigma sp., Surirella ovata). Thus, the species composition in the RS sediments differed clearly from that in the water column.

\section{Pigment concentrations (chlorophyll a:phaeopigment a)}

In the sediments of both study sites, highest chlorophyll a concentrations occurred mainly within the first sediment horizon of $1 \mathrm{~cm}$ depth (seasonal range of 13 to $48 \mu \mathrm{g} \mathrm{cm}^{-3}$ and 13 to $17 \mu \mathrm{g} \mathrm{cm}^{-3}$ at $\mathrm{KB}$ and RS, respectively), and decreased with increasing sediment depth (Fig. 2). In KB sediments, chlorophyll a concentrations were up to 9 times higher than the phaeopigment concentrations. In contrast, in the sediments at $\mathrm{RS}$, concentrations of active and degraded pigments were similar. Sediments at KB contained up to 3 times higher chlorophyll a concentrations than the sediments at RS (Fig. 2).
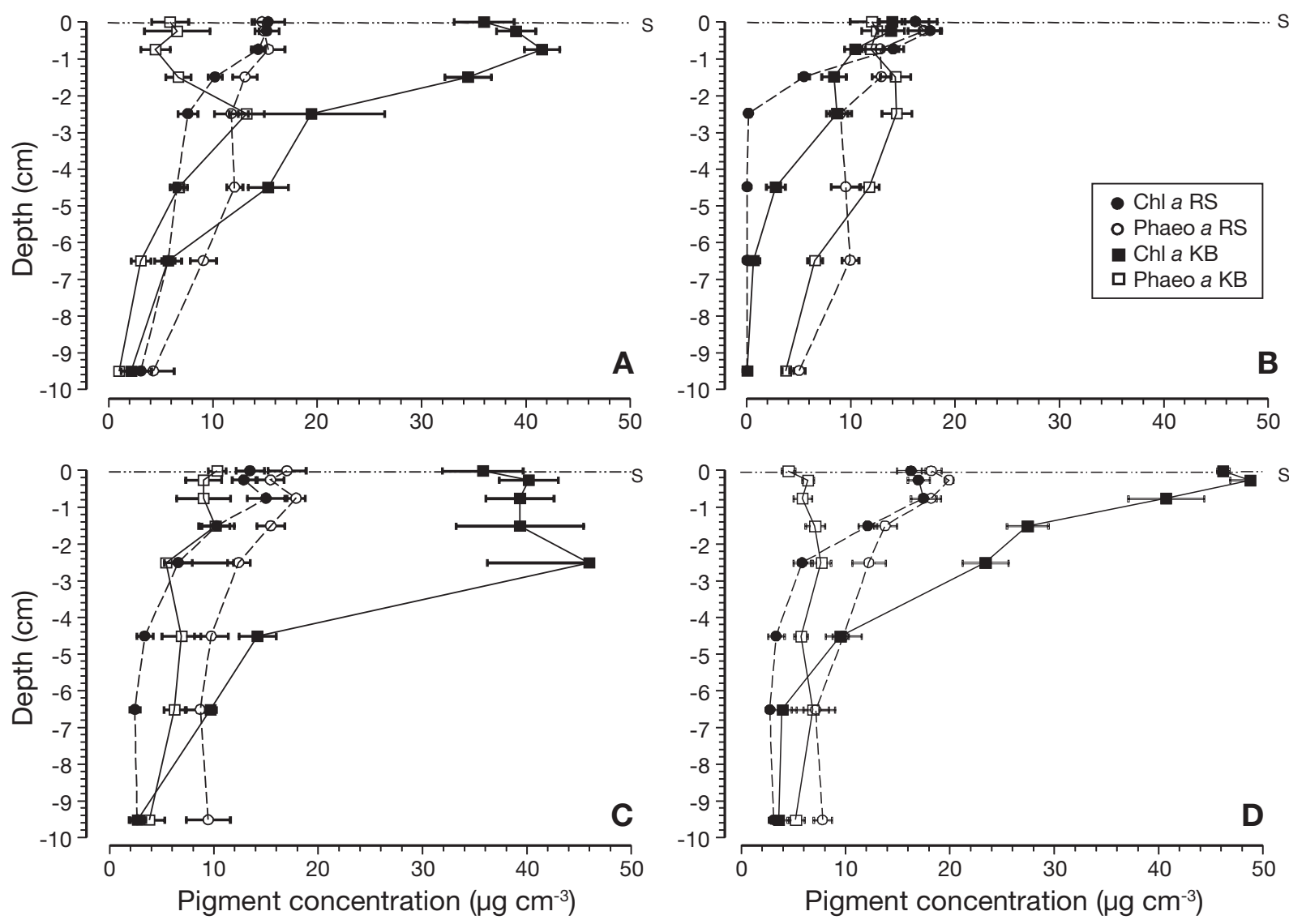

Fig. 2. Vertical profiles of chlorophyll $a(\mathrm{chl}$ a) and phaeopigment $a$ (phaeo a) concentrations in sediments of Kirr Bucht (KB) and Rassower Strom (RS) in (A) summer 1996, (B) autumn 1996, (C) winter 1997 and (D) spring 1997. Pigment detection began in the flocculent layer on top of the sediment surface $\left(\mathrm{S}_{1}, \ldots \ldots \ldots-\ldots\right)$ and continued downwards to a depth of $10 \mathrm{~cm}$ 


\section{Photic zone $\left(\mathrm{z}_{\mathrm{PAR}}\right)$}

According to the definition of the euphotic zone in the pelagic environment (Sommer 1998), the photic zone is defined as the sediment depth at which PAR is reduced to $1 \%$ of incident irradiance. Light intensity and light penetration were measured using spherical glass-fibre microsensors in the upper sediment horizons, which were exposed to various irradiances (Fig. 3). A clear light intensity peak was detected just below (Fig. 3A) and at (Fig. 3B) the sediment surface; the peak was most pronounced at higher light intensities. With increasing surface irradiance, the light penetrated significantly into deeper sediment layers to a maximum depth beyond which increases in incident irradiances did not result in further extension of the photic zone (Fig. 3). In the sandy sediments of $\mathrm{KB}$, the photic zone was always more pronounced than in the muddy sediments of RS ( $p<$ 0.0001, Table 2, Fig. 3). intensities at the sediment surface, the peaks of photosynthetic activity moved downwards in the sediment. In the sediments of RS, the highest gross production rates were always just beneath the sediment surface, e.g. $Z_{\text {phot, }}$ spring, $0.8 \mathrm{~mm} \mathrm{RS}$; Fig. 4B), even with increasing incident irradiance (data not shown). The extension of the photosynthetic active zone as well as the gross primary production rates were significantly higher in KB sediments than in RS sediments $(p<$ 0.0001; Table 2).

\section{Aerobic zone $\left(z_{\text {oxygen }}\right)$}

In correlation with increasing incident irradiance, the enhanced activity of photoautotrophic organisms led to higher oxygen production rates and an extended oxic layer in the upper sediment layers (Fig. 5). $z_{\text {oxygen }}$ is defined as the sediment depth at which $1 \mu \mathrm{mol} \mathrm{l^{-1 }}$ of oxygen concentration is de-

\section{Photosynthetic zone $\left(z_{\text {phot }}\right)$}

Increasing irradiance at the sediment surface leading to deeper light penetration into the sediment could activate photoautotrophic organisms in deeper layers. Nevertheless, the zone of photosynthetic activity did not extend to the full extent of the photic zone (Table 2, Fig. 4). In the sandy sediments of the $K B$, a zone with pronounced photosynthetic activity was detected (e.g. spring, $1.6 \mathrm{~mm}$ ), with several peaks of maximal oxygen production in deeper layers (Fig. 4A). With increasing light
Table 2. Mean $\pm \mathrm{SD}(\mathrm{n}=3$ to 10$)$ oxygen consumption $\left(\mathrm{O}_{2 \text { consum }}: \mathrm{mmol} \mathrm{O}_{2} \mathrm{~m}^{-1} \mathrm{~h}^{-1}\right)$ under dark conditions and extension $(\mu \mathrm{m})$ of aerobic zone $\left(z_{\text {oxygen }}\right)$ under dark and medium light conditions, and extension of photic layer $\left(z_{\mathrm{PAR}}\right)$ and photosynthetic active layer $\left(z_{\text {phot }}\right)$ under medium in situ light intensities in sediments of both study sites at different seasons. nd: not determined

\begin{tabular}{|c|c|c|c|c|c|}
\hline Date & $\begin{array}{c}\mathrm{O}_{2_{\text {consum }}} \\
\text { Dark }\end{array}$ & $\overline{\text { Dark }} z_{c}$ & $\begin{array}{l}\text { Oxygen } \\
\text { Medium light }\end{array}$ & $\begin{array}{c}Z_{\mathrm{PAR}} \\
\text { Medium light }\end{array}$ & $\begin{array}{c}Z_{\text {phot }} \\
\text { Medium light }\end{array}$ \\
\hline \multicolumn{6}{|l|}{ Kirr Bucht } \\
\hline 1 Jul 1996 & $-0.97 \pm 0.24$ & $1300 \pm 400$ & $1700 \pm 150$ & $2000 \pm 150$ & $800 \pm 170$ \\
\hline 7 Oct 1996 & $-0.66 \pm 0.19$ & $1800 \pm 150$ & $3200 \pm 150$ & $3000 \pm 400$ & $1100 \pm 300$ \\
\hline 27 Jan 1997 & $-0.60 \pm 0.08$ & $2500 \pm 150$ & $6100 \pm 210$ & $1900 \pm 0$ & nd \\
\hline 7 Apr 1997 & $-120 \pm 0.27$ & $2400 \pm 290$ & $4700 \pm 200$ & $3200 \pm 200$ & $1600 \pm 60$ \\
\hline \multicolumn{6}{|c|}{ Rassower Strom } \\
\hline 8 Jul 1996 & $-0.89 \pm 0.16$ & $1600 \pm 200$ & $3500 \pm 110$ & $1800 \pm 0$ & $570 \pm 60$ \\
\hline 30 Sep 1996 & $-0.79 \pm 0.15$ & $2300 \pm 230$ & $2600 \pm 500$ & $1600 \pm 100$ & $100 \pm 300$ \\
\hline 15 Jan 1997 & $-0.39 \pm 0.06$ & $3050 \pm 230$ & $2800 \pm 250$ & $1300 \pm 0$ & nd \\
\hline 14 Apr 1997 & $-0.72 \pm 0.15$ & $3400 \pm 220$ & $6700 \pm 140$ & $1500 \pm 150$ & $700 \pm 100$ \\
\hline
\end{tabular}
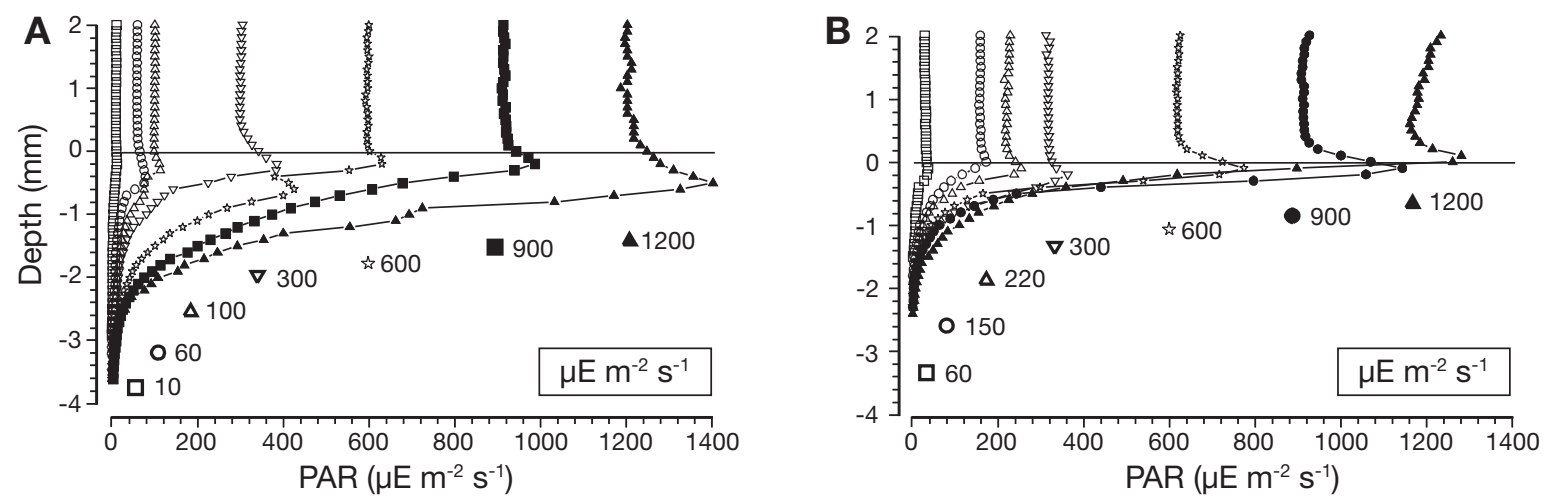

Fig. 3. Vertical light profiles in sediments of the (A) Kirr Bucht and (B) Rassower Strom, determined by a glass-fibre optical sensor at different illumination intensities in autumn 1996. Horizontal line at depth zero marks the sediment surface, with the negative values indicating sediment depth. PAR: photosynthetically active radiation 

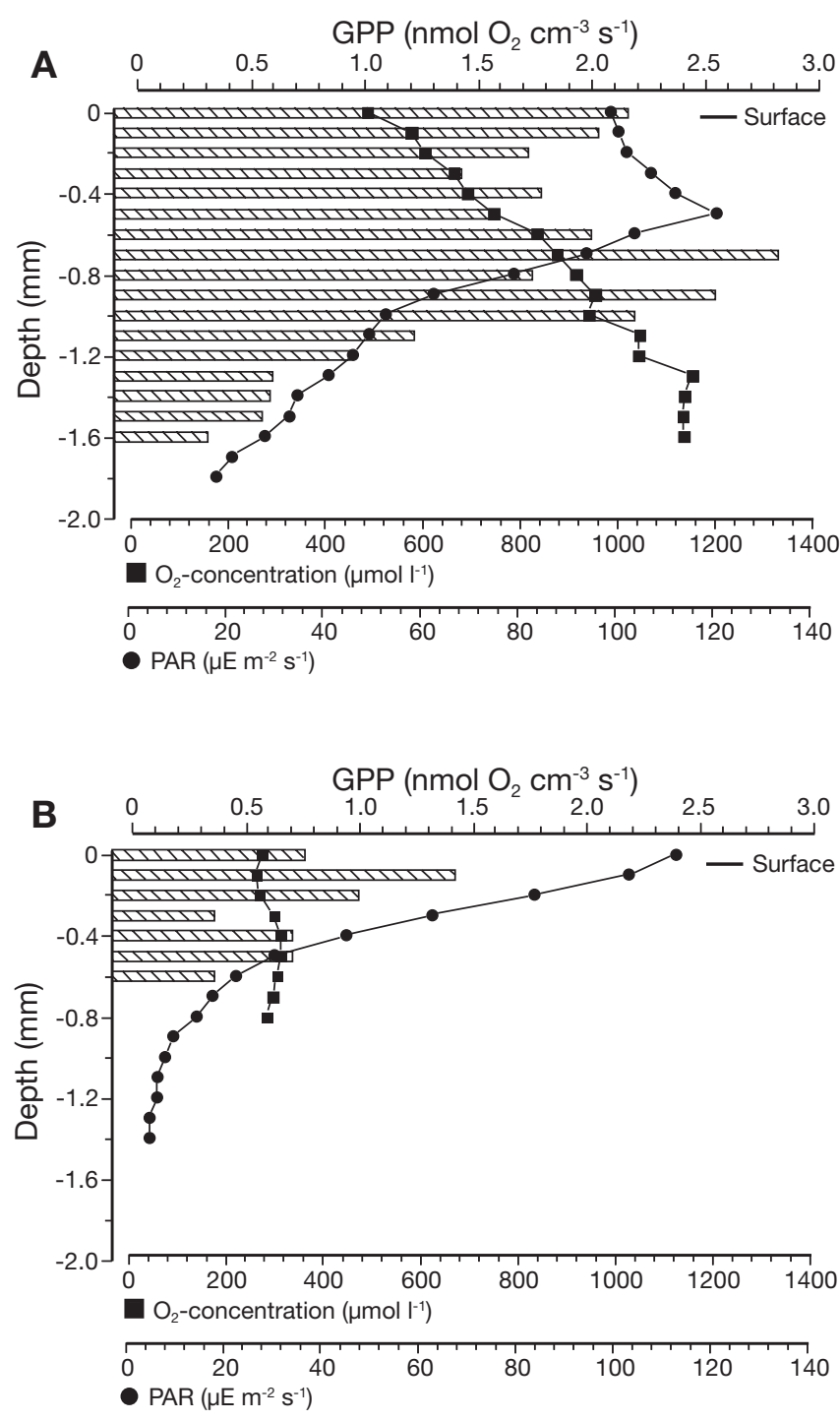

Fig. 4. Gross primary production, GPP (bars), oxygen concentrations and PAR at different sediment depths at medium in situ light intensity in spring 1997 at (A) Kirr Bucht and

(B) Rassower Strom

tectable. According to this definition, oxygen microprofiles indicated an extension of the aerobic zone of 1.3 to $2.5 \mathrm{~mm}$ and 1.6 to $3.4 \mathrm{~mm}$ (seasonal range; Table 2) in dark conditions in the sediments of the $\mathrm{KB}$ and RS, respectively (differences between the study sites were significant at the level $\mathrm{p}<0.0003$ ). Even under illumination, the extension of $z_{\text {oxygen }}$ was still higher in the RS sediments than in the KB sediments in spring and summer $(\mathrm{p}<0.0001$; Table 2$)$. Nevertheless, the higher benthic microalgal biomass and photosynthetic rates at $\mathrm{KB}$ resulted in up to 6 times higher maxima of oxygen concentrations in the upper sediment layers of KB compared to RS ( $p<$ 0.0001; Figs. 4 \& 5).
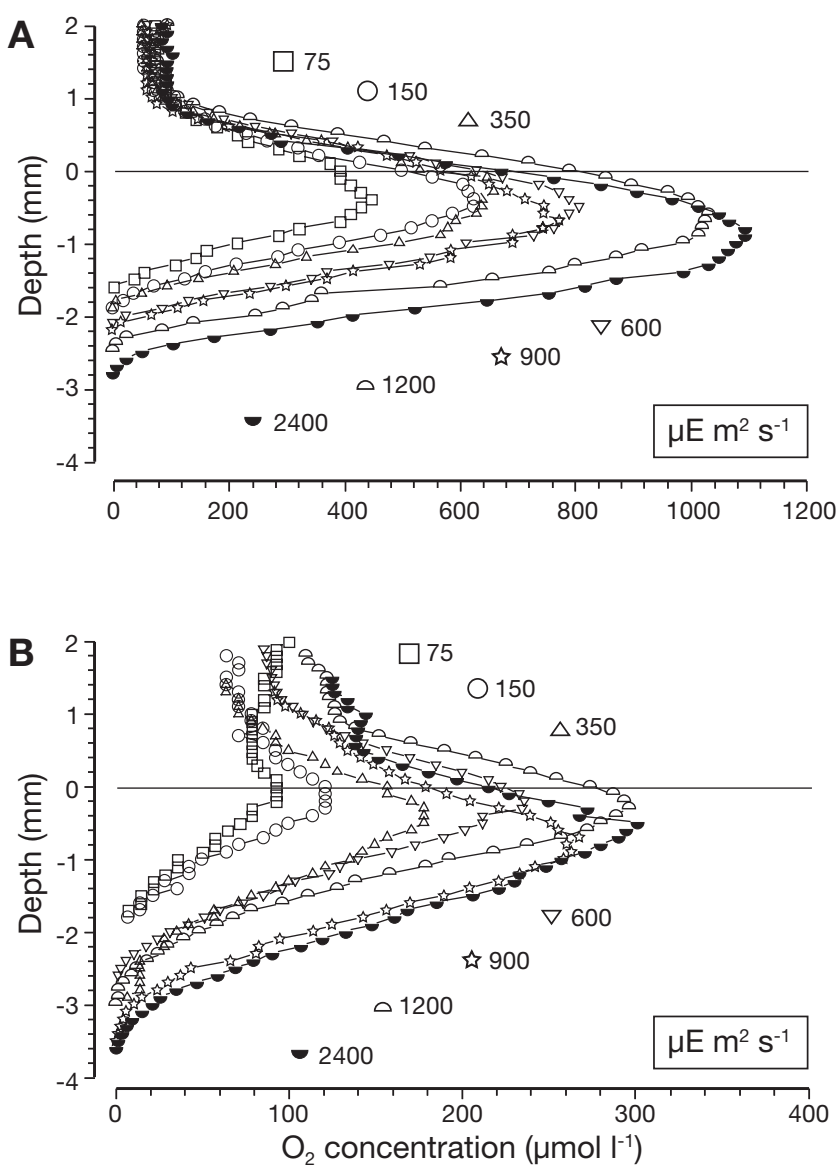

Fig. 5. Vertical oxygen profiles in sediments of the (A) Kirr Bucht and (B) Rassower Strom, determined by the oxygen Clark-type microelectrode under different illumination intensities in autumn 1996. Further details as for Fig 3

\section{Oxygen consumption and net primary production}

At both study sites, oxygen consumption and net primary production within the sediments (determined under dark and light conditions, respectively) showed a clear seasonal trend, with lowest rates in winter (Table 2, Fig. 6). Oxygen consumption and net primary production rates within the sandy $\mathrm{KB}$ sediments were both significantly higher than in the muddy RS sediments ( $<<0.0001$; Table 2, Fig. 6). Nevertheless, the ratios of gross oxygen production:oxygen consumption, representing photoautotrophic and heterotrophic processes (omitting for the latter the chemical oxygen demand in the sediment), were much higher in KB than RS, and most pronounced under the highest naturally occurring light intensities (seasonal range: $\mathrm{KB}$, 5 to 10 ; RS, 0.8 to 4 ). Nevertheless, the oxygen production in the RS sediments was sufficient to meet the oxygen demand even at low light intensities (except in winter), as indicated by the positive oxygen net fluxes. 

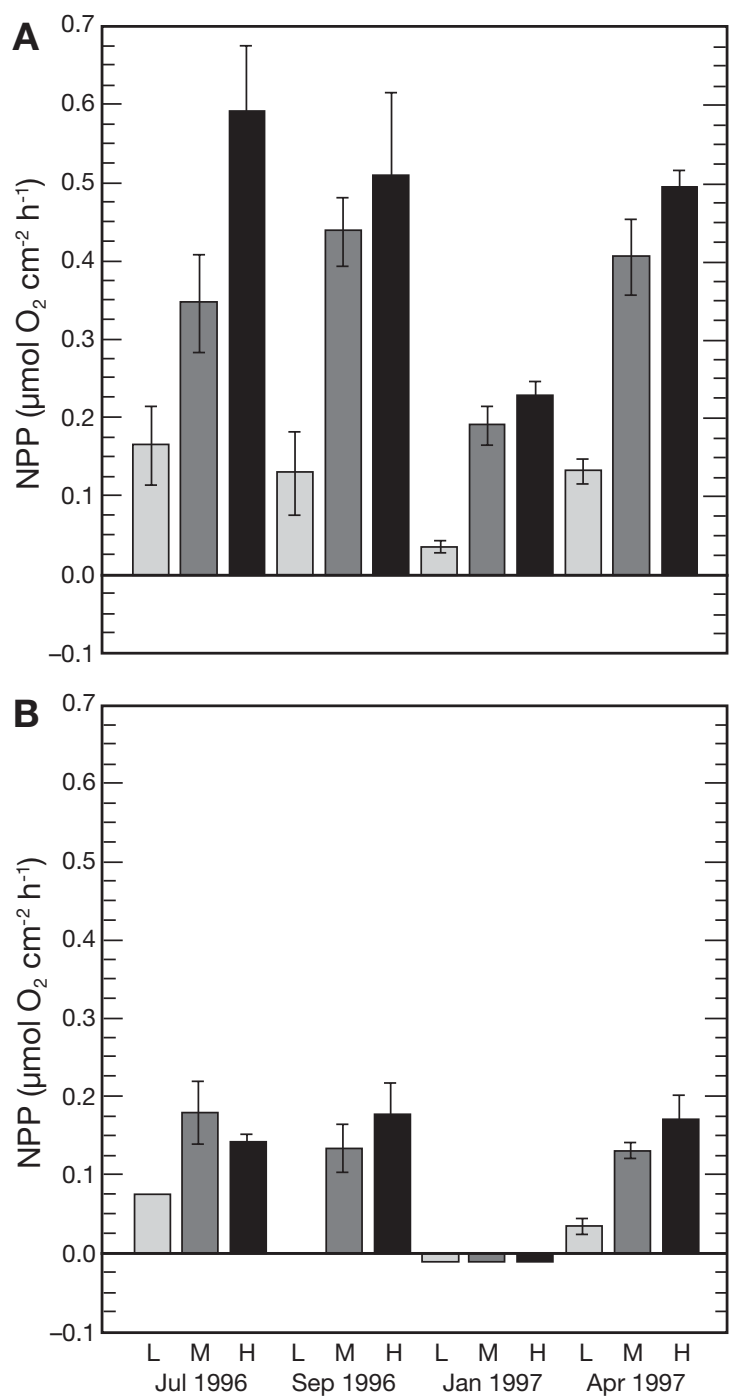

Fig. 6. Mean $( \pm \mathrm{SD})$ net primary production (NPP) of microphytobenthos in sediments of the (A) Kirr Bucht and (B) Rassower Strom, at different in situ light intensities (L: low; M: medium; H: high) in different seasons

\section{Gross primary production}

The areal gross primary production rates were significantly higher at KB than RS ( $\mathrm{p}=0.0282)$. Normalised to chlorophyll $a$, the gross primary production rates were still slightly higher in winter in the $\mathrm{KB}$ sediments than in the RS sediments, but were comparable in summer at the 2 sites (Fig. 7). In autumn 1996 and spring 1997, the specific production rates were significantly higher in the sediments of RS ( $\mathrm{p}<0.0001)$.

The $P^{B}{ }_{\text {max }}$ values, reflecting photosynthetic capacity under prevailing light conditions, showed a clear seasonal trend in KB sediments, but the trend was less pronounced for RS (Table 3, Fig. 7). Nevertheless, at
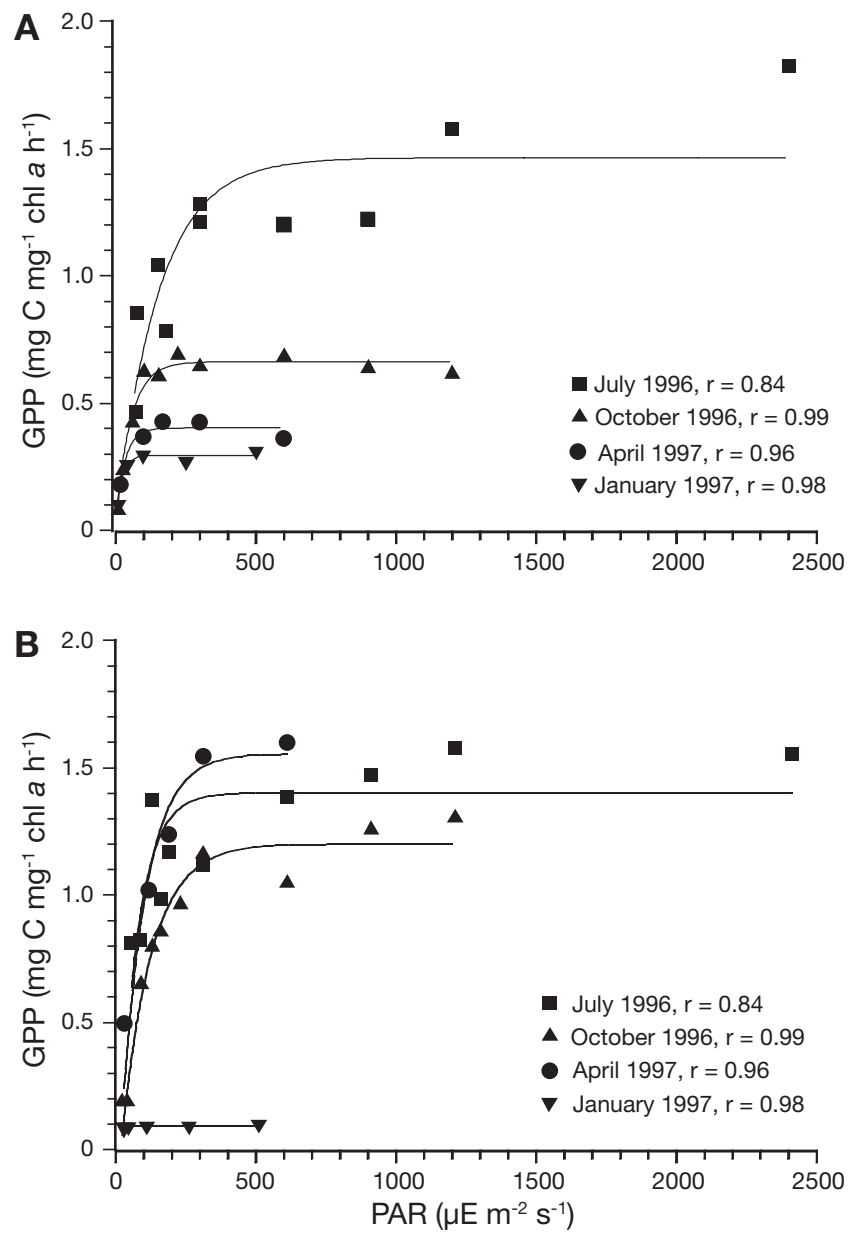

Fig. 7. Seasonal photosynthesis/irradiance $(P / E)$ curves for microphytobenthos in (A) Kirr Bucht and (B) Rassower Strom sediments calculated according to the model of Webb et al. (1974)

both sites, the maximal primary production rates followed seasonal changes in temperature $(\mathrm{r}=0.82$ and $0.71)$ and mean light intensities $(r=0.85$ and 0.76$)(\mathrm{KB}$ and $\mathrm{RS}$, respectively). The $\alpha^{B}$ values, reflecting photosynthetic efficiency, showed negative correlations with

Table 3. Parameters of photosynthesis/irradiance (P/E) curves; data normalised to chlorophyll a ( $\mathrm{chl} a)$, showing photosynthetic efficiency, $\alpha^{B}\left(\mathrm{mg} \mathrm{C} \mathrm{mg}{ }^{-1} \mathrm{chl} a\right) \mathrm{h}^{-1}\left(\mu \mathrm{E} \mathrm{m} \mathrm{m}^{-2}\right.$ $\left.\mathrm{s}^{-1}\right)^{-1}$, maximum photosynthetic capacity, $P^{B}{ }_{\max }\left(\mathrm{mg} \mathrm{C} \mathrm{mg^{-1 }}\right.$ $\left.\mathrm{chl} a \mathrm{~h}^{-1}\right)$, and light saturation, $E_{k}\left(\mu \mathrm{E} \mathrm{m} \mathrm{m}^{-2} \mathrm{~s}^{-1}\right)$ related to microphytobenthic primary production for both study sites in different seasons

\begin{tabular}{|ccccccc|}
\hline \multicolumn{3}{c}{ Kirr Bucht } & \multirow{2}{*}{ Month } & \multicolumn{3}{c|}{ Rassower Strom } \\
$\alpha^{B}$ & $P^{B}{ }_{\max }$ & $E_{k}$ & & & $P^{B}{ }_{\max }$ & $E_{k}$ \\
\hline 0.0096 & 1.46 & 152 & Jul 1996 & 0.0133 & 1.54 & 116 \\
0.0123 & 0.66 & 54 & Sep/Oct 1996 & 0.0121 & 1.28 & 106 \\
0.0131 & 0.29 & 22 & Jan 1997 & 0.0171 & 0.17 & 10 \\
0.0124 & 0.40 & 32 & Apr 1997 & 0.0189 & 1.63 & 86 \\
\hline
\end{tabular}


temperature ( $\mathrm{r}=0.75$ and 0.82$)$ and mean light conditions ( $\mathrm{r}=0.81$ and 0.76 ) ( $\mathrm{KB}$ and $\mathrm{RS}$, respectively). Thus, light saturation $E_{k}$, defined as the ratio $P_{\text {max }}^{B}: \alpha^{B}$, correlated with both temperature $(r=0.77$ and 0.93$)$ and mean light intensity $(r=0.82$ and 0.94$)(\mathrm{KB}$ and $\mathrm{RS}$, respectively).

\section{The benthic habitat-sink or source of oxygen?}

On the basis of the foregoing $\left(R, \alpha^{B}, P^{B}{ }_{\max }\right)$, and linked with respiration rates and the results of constant PAR measurements, the model of Walsby (1997) allowed interpolation of the net primary production rates for the time intervals between measurements. This was initially performed for the $24 \mathrm{~h}$ of each sampling day in the different seasons. Whereas for the $8 \mathrm{~h}$ illumination a positive oxygen flux was calculated even in the low light range at both study sites (except in winter at RS: Fig. 6), daily calculation of the oxygen budget indicated negative oxygen fluxes in summer and autumn for RS and in winter for KB (Fig. 8). For both study sites, integrated over $24 \mathrm{~h}$, the highest positive oxygen fluxes for the benthic habitat were calculated for spring.
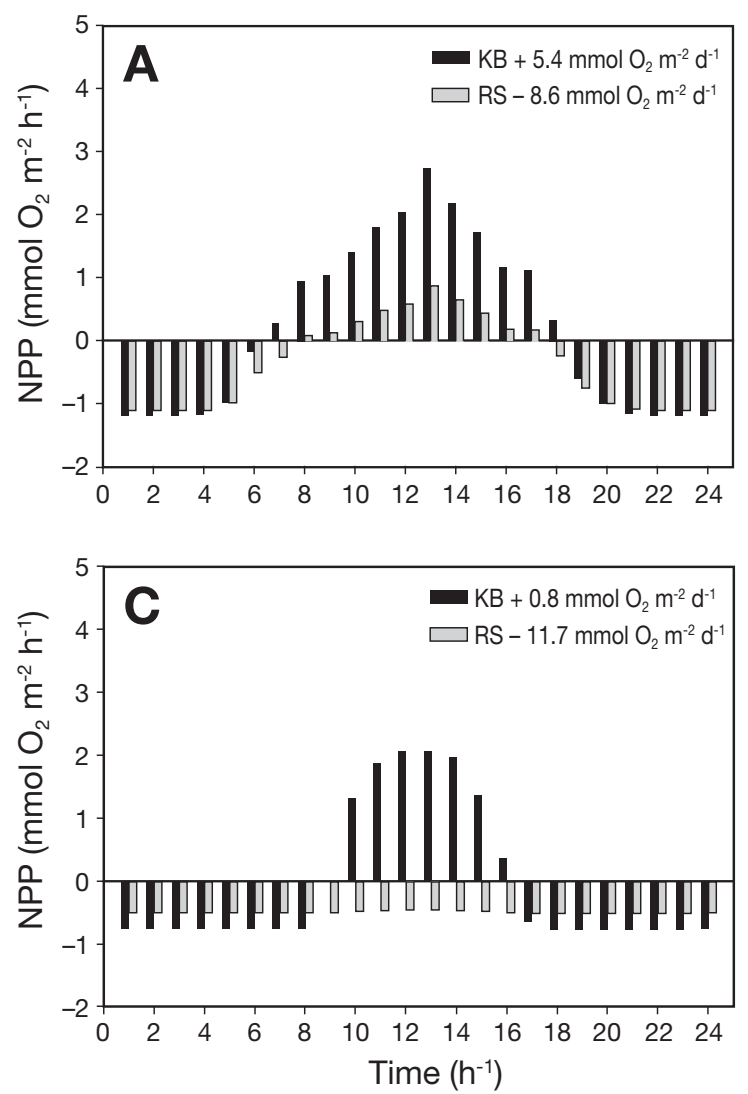

\section{Contribution of benthic primary production}

Since net oxygen production and respiration rates can be derived from oxygen microprofiles for sediments only, pelagic primary production was determined by the oxygen exchange method. The interpolation of the measured benthic and pelagic primary production rates over $24 \mathrm{~h}$ for those days on which measurements were made showed that the microphytobenthos contributed from 26 to $59 \%$ and 2 to $53 \%$ to the total primary production at $\mathrm{KB}$ and $\mathrm{RS}$, respectively. The relative contribution of benthic primary production was highest in spring at both sites. A further interpolation of the measured data with constantly determined PAR values and the Walsby (1997) model over the course of 1 yr showed that, as an annual average, the microphytobenthos accounted for 37 and $30 \%$ of the total primary production at KB and RS, respectively (Fig. 9). The carbon fixation rates by the microphytobenthos were calculated as 2 to $17 \mathrm{~g} \mathrm{C} \mathrm{m}^{-2} \mathrm{mo}^{-1}$ (113 $\mathrm{g} \mathrm{C} \mathrm{m}^{-2} \mathrm{yr}^{-1}$ ) for $\mathrm{KB}$ (Fig. 9A) and 0.2 to $7 \mathrm{~g} \mathrm{C} \mathrm{m}^{-2} \mathrm{mo}^{-1}$ (42 $\mathrm{g} \mathrm{C} \mathrm{m}^{-2} \mathrm{yr}^{-1}$ ) for RS (Fig. 9B). The pelagic gross production rates, integrated over the water depth, were 2 times higher in the shallow $\mathrm{KB}$ ( 5 to $30 \mathrm{~g} \mathrm{C} \mathrm{m}^{-2} \mathrm{mo}^{-1}, 190 \mathrm{~g} \mathrm{C} \mathrm{m}^{-2} \mathrm{yr}^{-1}$ ) than in the deeper RS (2 to $24 \mathrm{~g} \mathrm{C} \mathrm{m}^{-2} \mathrm{mo}^{-1}, 108 \mathrm{~g} \mathrm{C} \mathrm{m}^{-2} \mathrm{yr}^{-1}$ ) (Fig. 9).
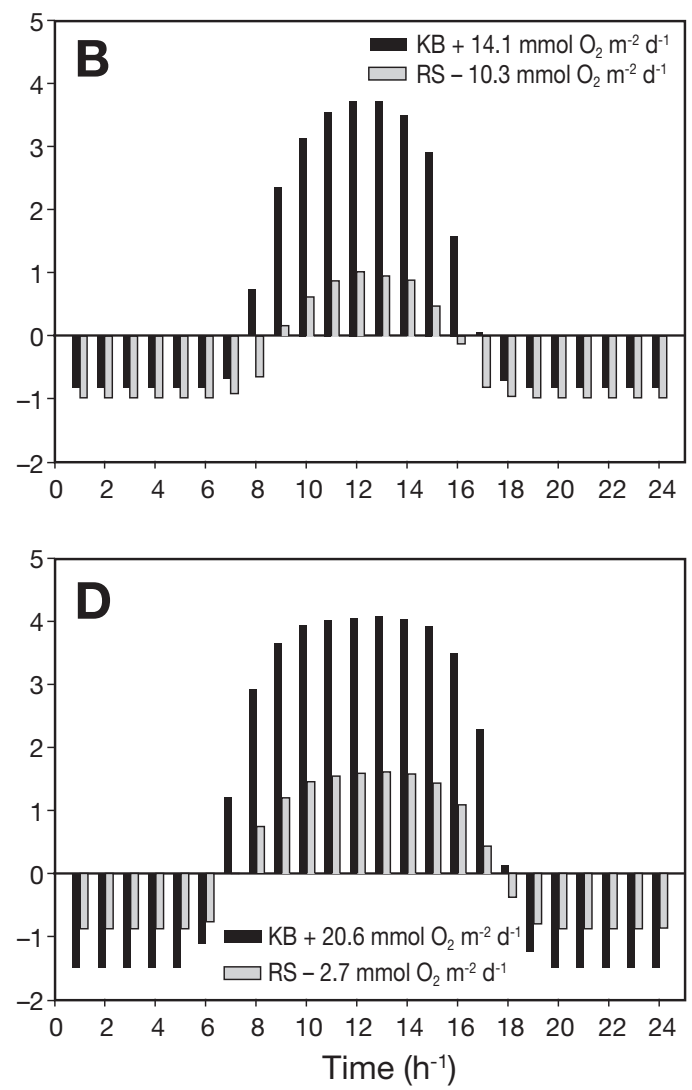

Fig. 8. Benthic net primary production (NPP), interpolated using Walsby's model (1997), over the days on which sampling was carried out (see Table 2) in Kirr Bucht and Rassower Strom sediments in different seasons. (A) summer 1996; (B) autumn 1996; (C) winter 1997; (D) spring 1997 


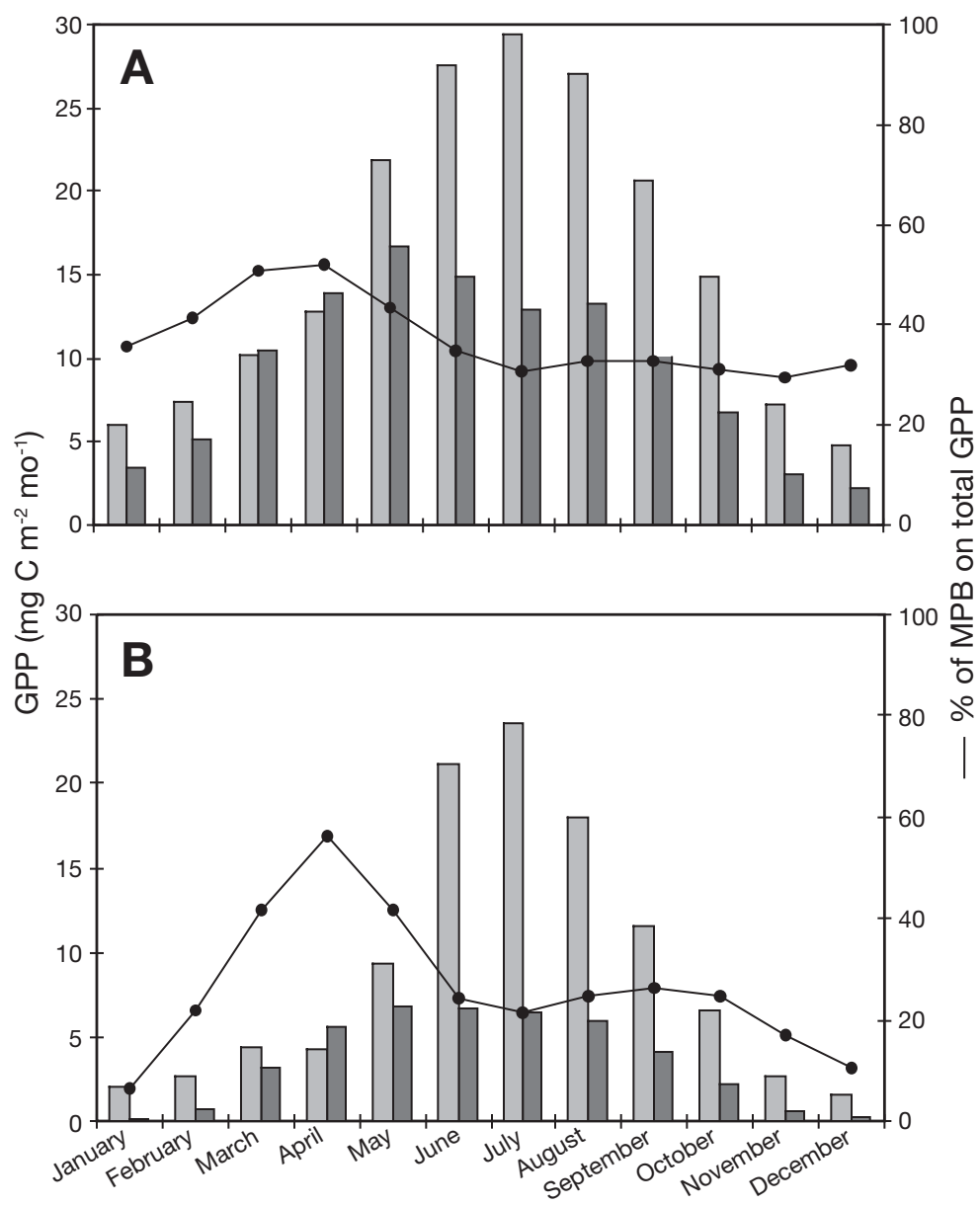

Fig. 9. Carbon fixation rates (gross primary production, GPP) for the benthal (black bars) and the pelagial (grey bars), interpolated using the Walsby model (1997) on a monthly basis, in the (A) Kirr Bucht and (B) Rassower Strom. Curve indicates contribution of photosynthetic activity of the microphytobenthos (MPB) to total GPP

\section{Microphytobenthos: light climate and species composition}

In recent decades, the nutrient load of municipal, agriculture and industrial water has led to an increase in phytoplankton biomass in the Bodden (Wasmund \& Schiewer 1994, Schiewer 1998), resulting in drastic changes in the underwater light field. Phytoplankton adds significantly to the scattering and absorption of light in the water column reducing light intensity and altering the spectral composition (Schubert et al. 2001, S. U. Gerbersdorf unpubl.). Thus, water transparency at the eutrophic study site, Kirr Bucht, was 4 to 6 times lower than at the mesotrophic study site, Rassower Strom. Nevertheless, at the sediment surface, light availability (the main abiotic factor influencing microphytobenthic photosynthesis) was similar in both areas due to different morphologies and water depths (KB, $0.6 \mathrm{~m}$; RS, $3.4 \mathrm{~m}$ ). However, the species composition of the benthic algae differed qualitatively at the 2 sites. Microscopic investigation revealed that Cyanobacteria of the order Chroococcales and Chlorophyceae of the order Chlorococcales were dominant on the sediment surface of $\mathrm{KB}_{\text {; }}$ with a similar composition of species (e.g. Gomphospheria lacustris, Merismopedia punctata, Scenedesmus quadricauda and Oocystis sp.) in the water column. Only a few benthic diatoms such as Gyrosigma balticum and Surirella sp. were present in $\mathrm{KB}$ sediments, indicating that most of the 'microphytobenthos' originated from the

\section{DISCUSSION}

The significance of microphytobenthic primary production for the aquatic habitat is obvious (Koop et al. 1990, Rizzo 1990, Wiltshire 1992, Berninger \& Epstein 1995, MacIntyre \& Cullen 1996, MacIntyre et al. 1996, de Brouwer et al. 2003). Nevertheless, only some 100 papers in the last few decades have examined the subject of microphytobenthos on a global scale, and even fewer have investigated the sublittoral zone. Until recently (Meyercordt et al. 1999, Gerbersdorf 2000, Gerbersdorf et al. 2004), almost no investigations on the microphytobenthos had been carried out in the Bodden areas of the southern Baltic Sea. The present study examined microphytobenthic primary production in 2 Bodden areas differing in trophic status, and thus in conditions for the microphytobenthos. overlying water column. In contrast, the species composition in the sediment and water column clearly differed at RS. The microphytobenthos at RS mainly consisted of pennate diatoms such as Navicula sp. and Amphora sp. However, in terms of oxygen and carbon supply, the sedimented pelagic algae in the $\mathrm{KB}$ are comparable to an actual microphytobenthos; thus, we have used the term 'microphytobenthos' for both study sites.

\section{Highly resolved measurements in the sediment}

Microelectrode studies are mainly known from the intertidal zone (e.g. Barranguet et al. 1998) or within microbial mats (e.g. Oren et al. 1995) and the investigations presented here are the first to use microsensors in the Bodden estuaries. The microsensors 
provided very detailed information on the spatial and temporal heterogeneity of light, photosynthetic activity and oxygen within the sediment itself. The sediments at both study sites had different soil characteristics, which altered the light climate within the sediment in predictable ways. The photic zone $\left(z_{\mathrm{PAR}}\right)$ in the sandy sediments of KB was about twice as deep (seasonal range 1.4 to $3.2 \mathrm{~mm}$ ) as that in the muddy sediments of RS (seasonal range 0.9 to $2.0 \mathrm{~mm}$ ) under in situ light intensities. This was in agreement with the findings of Jørgensen \& des Marais (1990) and Kühl et al. (1994), who determined a photic zone of 1.3 to 4.6 and 0.2 to $2.0 \mathrm{~mm}$ for sandy and muddy sediments, respectively. Light attenuation is determined mainly by absorption, which is stronger in sediments with higher organic content. If absorption is low, strong scattering can retain a high light intensity at a given depth; this is especially enhanced near optical boundaries, resulting in maximum scalar irradiance. This was seen within the first $1 \mathrm{~mm}$ of the strongly scattering, sandy sediment of $\mathrm{KB}$, leading to peaks in light intensity of up to $140 \%$ relative to incident light from above (up to $200 \%$ in sandy sediments investigated by Kühl et al. 1994 and Oren et al. 1995). In contrast, in RS sediments, pronounced light intensity peaks occurred directly at the sediment surface due to scattering and reflection. In agreement with literature data, the light attenuation coefficient for the first $5 \mathrm{~mm}$ sediment layer was much lower in the sandy sediments of KB than in the muddy sediments of RS (seasonal $k$ range of 0.4 to $1.0 \mathrm{~mm}^{-1}$ and 1.3 to $2.0 \mathrm{~mm}^{-1}$, respectively).

Under in situ irradiances, the photosynthetic active zone $\left(z_{\text {phot }}\right)$ ranged down to a maximum of $2 \mathrm{~mm}$ depth in KB sediments, but to a maximum depth of only $1 \mathrm{~mm}$ in RS sediments, as measured by the light/dark shift method. Consequently, $z_{\text {phot }}$ did not resemble $z_{\mathrm{PAR}}$ at either study site. Presumably, less than $20 \mu \mathrm{E} \mathrm{m}^{-2} \mathrm{~s}^{-1}$ was not sufficient to support the photosynthetic activity of the pelagic species in the $\mathrm{KB}$ sediments. At the same time, the pennate diatoms in RS sediments could migrate to upper layers with better light availability. Despite a generally more extensive $z_{\mathrm{PAR}}$ in KB sediments, $z_{\text {phot }}$ at this site was significantly more pronounced only in spring compared to RS. Nevertheless, at KB, 3 times higher pigment concentrations in the upper $0.5 \mathrm{~cm}$ (up to $50 \mu \mathrm{g}$ $\mathrm{cm}^{-3}$ ) resulted in significantly higher rates of photosynthetic activity and up to 6 times higher oxygen concentrations in the upper layers compared to RS (maximum of 1100 and $300 \mu \mathrm{mol} \mathrm{l^{-1 }}$, respectively). This did not necessarily lead to a higher oxygen penetration in KB sediments, as the oxygen consumption there was generally higher than in RS sediments. Consequently, the muddy RS sediments had higher oxygen penetration not only under dark conditions, but also under illumination in spring and summer. The question remains as to whether the higher oxygen supply in KB sediments leads to enhanced microbial processes, as indicated by the relatively high ratio of active and degraded pigments, or whether a greater supply of fresh organic material through primary production may have led to the higher oxygen consumption rates in the KB sediments. More important is the opportunity (now provided by microsensors) to examine the varying penetration of $z_{\text {oxygen }}$ in seasonal terms and its consequences in the sediments of both study sites.

\section{Significance of microphytobenthos}

The occurrence of many organisms is determined by the aerobic conditions within the sediment. Thus, the highest abundance and vertical distribution of meiofauna (Arlt \& Georgi 1999), heterotrophic flagellates and amoebae (Garstecki et al. 1999) as well as bacteria (Rieling 1999) (determined simultaneously in parallel investigations) matched the expansion of the aerobic zone at both study sites. In anoxic layers, sulphatereducing bacteria became dominant in the sediments of both study sites (Babenzien \& Voigt 1999). Furthermore, the importance of the aerobic layer to redox conditions and nutrient fluxes was shown by the release of manganese and iron (Stodian et al. 2000) and the release of $o$-phosphate and ammonia (Rieling et al. 2000) under anoxic conditions, whereas these compounds are bound to the sediment in oxidised form. The microphytobenthos also assimilates nutrients for photosynthetic activity, thereby reducing the nutrient fluxes of $o$-phosphate and ammonia under illumination significantly (Gerbersdorf et al. 2000, Rieling et al. 2000).

Initiated by illumination, migration towards the surface and photosynthetic activity of the algae lead to stabilisation of the sediment along with mat formation and EPS (extracellular polymeric substances) production/excretion (S. U. Gerbersdorf unpubl.). This is important in shallow waters, where even low winds can otherwise lead to resuspension events (Schnese 1973). With regard to the benthic-pelagic coupling, microbenthic algae can contribute not only to the oxygen and carbon supply within the sediment, but also to that in the water column through resuspension processes (Schiewer 1998). Therefore, in addition to investigating the spatial and temporal heterogeneity of the metabolic processes within the sediment itself, we examined the primary production of the microphytobenthos as one of the main driving forces in the carbon budget of these shallow waters. 


\section{Primary production of microphytobenthos}

The high benthic chlorophyll a concentrations in the KB sediments reflected the high biomass of phytoplankton at this eutrophic site, which was deposited on the sediment surface. Under in situ light conditions, the benthic gross primary production rates in $\mathrm{KB}$ sediments (28 to $80 \mathrm{mgC} \mathrm{m}^{-2} \mathrm{~h}^{-1}$ ) were 3 times higher than in RS. Thus, benthic primary production rates in $\mathrm{KB}$ sediments were well within the range of data for highly productive diatom associations in the Wadden Sea. Colijn \& de Jonge (1984) and Barranguet et al. (1998) determined benthic gross production rates of 10 to $115 \mathrm{mg} \mathrm{C} \mathrm{m}^{-2}$ $\mathrm{h}^{-1}$ and 11 to $58 \mathrm{mgC} \mathrm{m}^{-2} \mathrm{~h}^{-1}$ in the tidal zone, respectively, depending on season. Moreover, the photosynthetic rates in KB sediments at light intensities up to $350 \mu \mathrm{E} \mathrm{m} \mathrm{m}^{-2} \mathrm{~s}^{-1}$ were 1.5 times higher than in biofilms along an eutrophication gradient in Bodden waters (34.4 to $94.5 \mathrm{mgC} \mathrm{m}^{-2} \mathrm{~h}^{-1}$ at radiation levels of 100 to $800 \mu \mathrm{E} \mathrm{m} \mathrm{m}^{-2} \mathrm{~s}^{-1}$, Meyer-Reil \& Neudörfer 1998). In contrast, RS sediments had primary production rates ( 3 to $36 \mathrm{mgC} \mathrm{m}^{-2} \mathrm{~h}^{-1}$ ) that were comparable with data obtained for deeper sublittoral coastal areas. Gargas (1972) and Herndl et al. (1989) determined gross primary production rates of 0.5 to $21 \mathrm{mgC} \mathrm{m}^{-2} \mathrm{~h}^{-1}$ at $4 \mathrm{~m}$ depth and 10 to $13 \mathrm{mgC} \mathrm{m}^{-2}$ $\mathrm{h}^{-1}$ at 7 to $22 \mathrm{~m}$ depth, respectively. Nevertheless, the microphytobenthos at RS displayed as much as half of the photosynthetic activity measured in biofilms in Bodden waters (Meyer-Reil \& Neudörfer 1998), although biofilms are usually known as systems with high metabolic activities.

In regard to a possible decline in the microphytobenthos due to eutrophication, excessive phytoplankton development and decreasing light availability at the sediment surface, comparison of our data with earlier findings at the 2 study sites would have been of particular interest. Unfortunately, no data for RS and only a few earlier publications for KB are available for microphytobenthic primary production. Wasmund (1986) measured benthic primary production in a similar range to our data ( 7 to $117 \mathrm{mg} \mathrm{C} \mathrm{m}^{-2} \mathrm{~h}^{-1}$ ), but the sediments he investigated originated from a depth of only 15 to $20 \mathrm{~cm}$, which is much less than the water depth at our study site. It is not feasible to discuss the decline in microphytobenthos using the few data currently available, especially considering the well-known variations in primary production rates that can occur within a few hours even at the same investigation point (Blanchard et al. 2001). Monitoring programmes are strongly recommended to reveal possible effects of eutrophication on the microphytobenthos on a longterm basis.

\section{Physiological adaptations of microphytobenthos}

Over the course of the year, photosynthetic rates varied not only as a function of biomass, but also (strongly) as a function of abiotic factors (temperature, $\mathrm{r}=0.82$ and 0.71 ; light, $\mathrm{r}=0.85$ and 0.76 , for $\mathrm{KB}$ and $\mathrm{RS}$, respectively), in accordance with reports in the literature (e.g. Blanchard \& Guarini 1996). Temperature affects the specific activities of enzymes (Epping 1996), which in turn affect $C$-assimilation as well as the electron transport chain (Kohl \& Nicklisch 1988). Light intensity determines photosynthetic capacity by influencing the orientation, size and number of reaction centres and the capacity of the Calvin cycle (Kohl \& Nicklisch 1988). Since temperature and light were comparable at the sediment surface of both study sites, no significant differences in the physiological adaptations of the 2 algal communities would be expected. Nevertheless, the parameters of the $P / E$ curves such as photosynthetic capacity $\left(P_{\max }\right)$, photosynthetic efficiency $(\alpha)$ and light saturation $\left(E_{k}\right)$, should indicate general adaptations of the benthic algae to, for example, low light regimes when data from both study sites are compared with data in the literature (Kohl \& Nicklisch 1988, Pickney \& Zingmark 1991, Falkowski \& Raven 1997. Barranguet et al. 1998).

Normalised for chlorophyll $a$, the $P^{B}{ }_{\max }$ maximum photosynthetic values were (except for winter) lower for KB benthic microalgae than for those at RS, although the medium light availability at the sediment surface was comparable or even higher at KB. This could indicate nutrient limitation at times of high photosynthetic activities in the sediment, as described by Sundbäck \& Snoeijs (1991), although usually nutrient limitation in the benthic habitat is less likely because benthic microalgae can assimilate nutrients directly out of the interstitial water (Shaffer \& Onuf 1983). Also, the high benthic algal biomass in the upper layers of the $\mathrm{KB}$ sediments could have shaded the algae in deeper layers, resulting in lower mean photosynthetic capacity rates integrated over the depths measured. MacIntyre \& Cullen (1996) demonstrated higher $P^{B}{ }_{\text {max }}$ values in the upper than the lower sediment depths (6 to 10 compared to 0.6 to $2.8 \mathrm{mgC} \mathrm{mg}^{-1} \mathrm{chl} \mathrm{a} \mathrm{h}^{-1}$ ) as a result of adaptation to different light conditions. The $P^{B}{ }_{\text {max }}$ values in the present paper were in the range of 0.17 to $1.63 \mathrm{mgC} \mathrm{mg}^{-1} \mathrm{chl} \mathrm{a} \mathrm{h}^{-1}$ at both study sites and thus comparable to data from other sublittoral offshore regions. Plante-Cuny \& Bodoy (1987) determined $P^{B}{ }_{\max }$ of 0.46 to $1.23 \mathrm{mgC} \mathrm{mg}^{-1} \mathrm{chl} \mathrm{a} \mathrm{h}^{-1}$ in sandy sediments at $0.5 \mathrm{~m}$ depth in the Golfe de Fos, France. In the Wadden Sea, the algae experience temporally higher light intensities and temperature, resulting in higher chlorophyll-specific production rates. Thus, Pickney \& Zingmark (1991) reported variation in $P^{B}{ }_{\max }$ between 
0.27 and $4.42 \mathrm{mg} \mathrm{C} \mathrm{mg}^{-1} \mathrm{chl} \mathrm{a} \mathrm{h}^{-1}$, with highest values at low tide. Barranguet et al. (1998) measured photosynthetic capacity of up to $13 \mathrm{mgC} \mathrm{mg}^{-1} \mathrm{chl} \mathrm{a} \mathrm{h}^{-1}$ in tidal areas of the Dutch Wadden Sea.

Together with the $\alpha^{B}$ values, which indicate the photosynthetic efficiency of photon utilisation, the photosynthetic capacity, $P^{B}$ max determines the light saturation value $E_{k}$ an indicator for photosynthetic acclimatisation to prevailing light conditions. In general, relatively low $E_{k}$ is expected under low light conditions, when benthic microalgae utilise the photon flux more efficiently (relatively high $\alpha^{B}$ ) and achieve maximal photosynthetic activity quite quickly (relatively low $P_{\text {max }}^{B}$ ). As for $P_{\text {max }}^{B}, \alpha^{B}$ and $E_{k}$ were correlated with temperature and light conditions at both study sites over the course of the year $\left(P^{B}\right.$ max and $E_{k}$ positively, $\alpha^{B}$ negatively). The seasonal $E_{k}$ values ranged from 22 to $152 \mu \mathrm{E} \mathrm{m}^{-2} \mathrm{~s}^{-1}$ and from 10 to $116 \mu \mathrm{E}$ $\mathrm{m}^{-2} \mathrm{~s}^{-1}$ for KB and RS, respectively, and reflected adaptations of the microalgae to rather low light conditions at both study sites. This agrees with data in the literature, which cover a broad range of light saturation values (e.g. Robinson et al. 1995, McMurdo Sound, Antarctica: 1.3 to $4.5 \mu \mathrm{E} \mathrm{m} \mathrm{m}^{-2} \mathrm{~s}^{-1}$; Whitney \& Darley 1983, sand bank in Georgia: $2044 \mu \mathrm{E} \mathrm{m}^{-2} \mathrm{~s}^{-1}$ ). The $E_{k}$ values in the present paper were comparable to values for the tidal zone during high tide reported by Colijn \& Van Buurt (1975), where the turbidity of the water column led to high light attenuation and mean $E_{k}$ values of $165 \mu \mathrm{E} \mathrm{m} \mathrm{m}^{-2} \mathrm{~s}^{-1}$.

\section{The benthic habitat — sink or source of oxygen?}

Under medium to maximum in situ light intensities, maximum photosynthetic capacity of the microphytobenthos was achieved at all seasons and at both study sites. The resulting photosynthetic oxygen production was able to meet the oxygen demand of the sediment, as indicated by positive oxygen fluxes at both study sites and at all seasons investigated, except in winter at RS. Nevertheless, the benthic microalgae only experienced these irradiances during approximately $8 \mathrm{~h}$ of total illumination around noon on an annual average. Applying the model of Walsby (1997), the data on oxygen consumption and production were interpolated over $24 \mathrm{~h}$ for the various sampling days (see Table 2) using the determined respiration rates, $P / E$, and the constantly measured PAR values. The daily oxygen budget of the benthic habitat (integrating dark and light periods) displayed negative oxygen fluxes for RS sediments in January, July and October and for $\mathrm{KB}$ sediments in January. Although photosynthetic activity and the light field are highly dynamic, interpolation of the data on a monthly basis revealed the days cho- sen for our measurements to be representative for both locations. Accordingly, the KB sediments could be a source of oxygen except in wintertime, and the RS sediments mainly a sink of oxygen except from late spring to summer.

\section{Contribution of microphytobenthos to total primary production}

To estimate the significance of microphytobenthic primary production in relation to total primary production, the pelagic primary production rates must be taken into consideration. Because microelectrodes can only be used in the sediment, the photosynthetic activity of phytoplankton was determined by the oxygen exchange method. Both methods are well-fitted to the nature of the relevant samples (pelagic production-exchange method for oxygen development and detection within the water, benthic production-microelectrodes method for oxygen development and detection within the sediment) and thus, little difference resulting from methodology was expected between the data sets for pelagic and benthic primary production. For sediment samples, microelectrodes gave much more reliable results on benthic primary production than more integrative methods such as oxygen exchange measurements. Microelectrodes measure photosynthetic activity directly at the production spot within the sediment, and both upward and downward oxygen fluxes are included (Revsbech et al. 1981). Hence, gross benthic primary production rates calculated on a monthly basis in the present paper (KB: 2 to $17 \mathrm{~g} \mathrm{C} \mathrm{m}^{-2} \mathrm{mo}^{-1}$; RS: 0.2 to $7 \mathrm{~g} \mathrm{C} \mathrm{m}^{-2} \mathrm{mo}^{-1}$ ) were on average 2 times higher than those reported by Meyercordt \& Meyer-Reil (1999), who used the oxygen exchange method. The differences in benthic primary production rates determined by both methods were more pronounced under the low light regime, where oxygen production was at or below the detection limit of the oxygen exchange approach (Gerbersdorf 2000).

Benthic and pelagic primary production rates were interpolated over the days on which sampling was carried out. On these days, the microphytobenthos accounted for about 26 to 59 and 2 to $53 \%$ of the total primary production in $\mathrm{KB}$ and $\mathrm{RS}$, respectively. The highest contribution ( $>50 \%$ ) to primary production by the benthic algae was for spring, corresponding with the best light conditions at the sediment surface, while the lowest contribution (19 to $26 \%$ ) was for summer (except for winter at RS, where their contribution was exceptionally low), corresponding with low light availability on that particular sampling day. In regard to the high variability in the light field, the interpolation of data on a monthly basis allowed more general con- 
clusions as to the significance of microphytobenthic photosynthetic activities in the aquatic environment. Again, the lowest ratio of pelagic to benthic primary production was for early spring, when the chlorophyll a concentrations in the water column indicated a $30 \%$ lower phytoplankton biomass resulting in a better light availability at the sediment surface compared to summer and autumn. During the course of the year, the contribution of the microphytobenthos to total primary production was substantial and comparable at both study sites ( 37 and $30 \%$ for KB and RS, respectively). This can be explained by the morphology (water depth at $\mathrm{KB}=0.6 \mathrm{~m}$, at $\mathrm{RS}=3.4 \mathrm{~m}$ ) and hydrography (light attenuation at $\mathrm{KB} k=3.17 \mathrm{~m}^{-1}$, at RS $k=0.61 \mathrm{~m}^{-1}$ ), at the 2 sites, which produced a similar light climate at the sediment surface of both areas. Only by calculating the benthic primary production for varying water depths and taking into account the different water transparency at each site could the effect of eutrophication be revealed.

\section{Effects of trophic status}

Because of the turbid and phytoplankton-rich water column in the eutrophic $\mathrm{KB}$, no light would be available at the sediment surface with a theoretical water depth of $3.4 \mathrm{~m}$ (the actual depth of the RS site), and thus, no benthic photosynthetic activity would be possible there. In contrast, at the mesotrophic RS, significant benthic primary production was measured at this water depth over the course of the year, except in winter. Based on a common depth of $0.6 \mathrm{~m}$ (the actual depth of the KB site), the benthic primary production rates would be similar at both study sites (Meyercordt \& Meyer-Reil 1999), despite much less benthic microalgal biomass at the RS. Assuming a common water depth of $2 \mathrm{~m}$, resembling the mean water depth of the Bodden, Meyercordt et al. (1999) showed that the microphytobenthos would support 30 to $45 \%$ of the total primary production at RS, but only $\leq 0.3 \%$ at KB. These calculations all support the hypothesis that eutrophication coupled with excessive phytoplankton development and decreasing light availability at the sediment surface has strong negative impacts on microphytobenthic primary production.

\section{CONCLUSION}

The present study has shown the significance of the microphytobenthos for the oxygen supply and carbon budget of the benthic habitat (and, via resuspension, to the pelagic environment also), as evidenced by its primary production rates in the shallow Bodden estu- aries. The contribution of the benthic microalgae in terms of total primary production is substantial, and because of the higher sensitivity of the detection method used (microelectrodes as opposed to the oxygenexchange method), even higher than that reported in former publications. Taking into account the different water depths and water transparencies at the 2 study sites (eutrophic/mesotrophic status), the negative impact of nutrient load and enhanced light attenuation caused by excessive phytoplankton development on microphytobenthic photosynthetic activity was revealed. A true microphytobenthos was established at the mesotrophic study site, while pelagic algae species dominated on the sediment surface at the eutrophic site. A shift in benthic microalgal species composition could have serious consequences such as effects on productivity (different photon flux efficiencies) or sediment stability (differential EPS production). Although the input of sewage into rivers and coastal areas has been significantly reduced over the last few decades (e.g. through the construction of numerous sewage treatment plants), the internal load of nutrients within the sediment (i.e. 'legacy of the past') remains a problem. Hence, monitoring programmes are still necessary to assess the risks and evaluate possible effects of eutrophication on the aquatic environment and enable development of appropriate remediation strategies in endangered areas.

Acknowledgements. The authors thank the crew of RV 'Professor Fritz Gessner' for assistance during sampling and Marion Köster, Ingrid Kreuzer, Frank Neudörfer, Georg Schubert, Joachim Timm and Wolfgang Zenke for excellent technical support. The authors are grateful to Helmut Hübel and Kirsten Wolfstein for enthusiastic teaching and help in the determination of algal species. The investigations presented here were part of the joint research project 'ÖKOBOD' (Ökosystem Boddengewässer-Organismen und Stoffhaushalt) financed by the German BMBF (Bundesministerium für Bildung, Wissenschaft Forschung und Technologie).

\section{LITERATURE CITED}

Arlt G, Georgi F (1999) Meiofauna in der bentho-pelagischen Kopplung. In: Black HJ, Köster M, Meyer-Reil LA (eds) Ökosystem Boddengewässer-Organismen und Stoffhaushalt (ÖKOBOD), BMBF. Abschlußbericht, Verbundprojekt, Bodden 8. Institut für Ökologie der EMAU Greifswald, Kloster/Hiddensee, p 19-24

Armitage P, Berry G (1994) Statistical methods in medical research. Blackwell Scientific, Oxford

Babenzien HD, Voigt A (1999) Bedeutung der Sulfatreduktion. In: Black HJ, Köster M, Meyer-Reil LA (eds) Ökosystem Boddengewässer - Organismen und Stoffhaushalt (ÖKOBOD), Abschlußbericht, Verbundprojekt, Bodden 8. Institut für Ökologie der EMAU Greifswald, Kloster/Hiddensee, p 67-72

Bachor A, von Weber M, Wiemer R (1996) Die Entwicklung der Wasserbeschaffenheit der Küstengewässer Mecklenburg-Vorpommerns. Nährstoffeinträge aus Mecklenburg- 
Vorpommern in die Ostsee 1990-1995. Wasser Boden 48: 26-36

Baly ECC (1935) The kinetics of photosynthesis. Proc R Soc Lond Ser 117:218-239

Barnett PRO, Watson J, Connelly D (1984) A multiple corer for taking virtually undisturbed samples from shelf, bathyal and abyssal sediments. Oceanol Acta 7:339-409

Barranguet C, Kromkamp J, Peene J (1998) Factors controlling primary production and photosynthetic characteristics of intertidal microphytobenthos. Mar Ecol Prog Ser 173:117-126

Behrens J (1982) Soziologische und produktionsbiologische Untersuchungen an submersen Pflanzengesellschaften der Darß-Zingster Boddengewässer. PhD dissertation, Universität Rostock

Berninger UG, Epstein SS (1995) Vertical distribution of benthic ciliates in response to the oxygen concentration in an intertidal North Sea sediment. Aquat Microb Ecol 9:229-236

Blanchard GF, Guarini JM (1996) Studying the role of mud temperature on the hourly variation of the photosynthetic capacity of microphytobenthos in intertidal areas. C R Acad Sci Sér III Sci Vie 319:1153-1158

Blanchard GF, Guarini JM, Orvain F, Sauriau PG (2001) Dynamic behaviour of benthic microalgal biomass in intertidal mudflats. J Exp Mar Biol Ecol 264:85-100

Börner R, Kell V (1982) Einfluß von Nährstoffanreicherungen auf die Biomasse, Artensequenz und Primärproduktion des Phytoplanktons während einer Komplexanalyse im Zingster Strom (Juni 1981). Wiss Z Wilhelm-Pieck-Univ Rostock Math-Natwiss Reihe 31:53-56

Burris JE (1981) Effects of oxygen and inorganic carbon concentrations on the photosynthetic quotients of marine algae. Mar Biol 65:215-219

Cadée GC, Hegeman J (1974) Primary production of the benthic microflora living on tidal flats in the Dutch Wadden Sea. Neth J Sea Res 8:260-291

Colijn F (1982) Light absorption in the waters of the EmsDollard estuary and its consequences for the growth of phytoplankton and microphytobenthos. Neth J Sea Res 15:196-216

Colijn F, de Jonge VN (1984) Primary production of microphytobenthos in the Ems-Dollard estuary. Mar Ecol Prog Ser 14:185-196

Colijn F, Van Buurt G (1975) Influence of light and temperature on the photosynthetic rate of marine benthic diatoms. Mar Biol 31:209-214

Correns M, Jäger F (1979) Beiträge zur Hydrographie der Nordrügenschen Bodden. I. Einführung in das Untersuchungsgebiet. Wasserstandsverhältnisse und Wasserhaushalt. Acta Hydrophys 24:149-177

Correns M, Jäger F (1982) Beiträge zur Hydrographie der Nordrügenschen Bodden. II. Strömungsverhältnisse, Salzund Sauerstoffhaushalt. Acta Hydrophys 27:5-22

de Brouwer JFC, De Deckere EMGT, Stal LJ (2003) Distribution of extracellular carbohydrates in three intertidal mudflats in Western Europe. Estuar Coast Shelf Sci 56:313-324

Epping EHG (1996) Benthic phototrophic communities and the sediment-water exchange of oxygen, Mn(II), Fe(II), and silicic acid. PhD dissertation, Rijksuniversiteit Groningen

Falkowski PG, Raven JA (1997) Aquatic photosynthesis. Blackwell Science, Oxford

Gargas E (1972) Measurements of microalgal primary production (phytoplankton and microbenthos) in the Smalandshavet (Denmark). Ophelia 10:75-89

Garstecki T, Güber A, Premke K, Verhoeven R, Arndt H, Wick- ham SA (1999) Trophische Beziehungen innerhalb benthischer mikrobieller Nahrungsgewebe. In: Black HJ, Köster M, Meyer-Reil LA (eds) Ökosystem Boddengewässer — Organismen und Stoffhaushalt (ÖKOBOD), Abschlußbericht, Verbundprojekt, Bodden 8. Institut für Ökologie der EMAU Greifswald, Kloster/Hiddensee, p 29-38

Gerbersdorf SU (2000) Die pelagische und mikrophytobenthische Primärproduktion in den Boddengewässern unter Berücksichtigung der Sedimentauflage, ihrer Fraktionen und Aggregate. PhD dissertation, Universität Greifswald

Gerbersdorf SU, Meyercordt J (1999) Primärproduzierende Prozesse in Pelagial und Benthal. In: Black HJ, Köster M, Meyer-Reil LA (eds) Ökosystem BoddengewässerOrganismen und Stoffhaushalt (ÖKOBOD), Abschlußbericht, Verbundprojekt, Bodden 8. Institut für Ökologie der EMAU Greifswald, Kloster/Hiddensee, p 39-47

Gerbersdorf SU, Black HJ, Meyercordt J, Meyer-Reil LA, Rieling T, Stodian I (2000) Significance of microphytobenthic primary production in the Bodden (southern Baltic Sea). In: Flemming BW, Delafontaine MT, Liebezeit G (eds) Muddy coasts dynamics and resource management. Proc Mar Sci, Vol 2. Elsevier Science BV, Amsterdam, p $127-136$

Gerbersdorf SU, Meyercordt J, Meyer-Reil LA (2004) Microphytobenthic primary production within the flocculent layer, its fractions and aggregates, studied in two shallow Baltic estuaries of different eutrophic status. J Exp Mar Biol Ecol 307:47-72

HELCOM (Helsinki Commission) (1988) Guidelines for the Baltic Monitoring Programme for the third stage. Loose sheet version of the Baltic Sea Environment Proceedings No. 27D. Helsinki Commission, Helsinki, p 1-60

Herndl GJ, Peduzzi P, Fanuko N (1989) Benthic community metabolism and microbial dynamics in the Gulf of Trieste (Northern Adriatic Sea). Mar Ecol Prog Ser 53:169-178

Hübel H (1968) Die Bestimmung der Primärproduktion des Phytoplanktons der Nordrügenschen Boddenkette unter Verwendung der Radiokohlenstoffmethode. Int Rev Gesamten Hydrobiol 53:601-633

Hübel H, Wolff C, Meyer-Reil LA (1998) Salinity, inorganic nutrients, and primary production in a shallow coastal inlet in the Southern Baltic Sea (Nordrügenschen Bodden) Results from long-term observations (1960-1989). Int Rev Gesamten Hydrobiol 83:479-499

Jassby AD, Platt T (1976) Mathematical formulation of the relationship between photosynthesis and light for phytoplankton. Limnol Oceanogr 21:155-168

Jørgensen BB, des Marais DJ (1990) The diffusive boundary layer of sediments: oxygen microgradients over a microbial mat. Limnol Oceanogr 35:1343-1355

Jørgensen BB, Revsbech NP (1985) Diffusive boundary layers and the oxygen uptake of sediments and detritus. Limnol Oceanogr 30:111-122

Karsten U, Kühl M (1996) Die Mikrobenmatte-das kleinste Ökosystem der Welt. Biol Unserer Zeit 26:16-26

Kohl JG, Nicklisch A (1988) Ökophysiologie der Algen. Gustav Fischer, Jena

Koop K, Boynton WR, Wulff F, Carman R (1990) Sedimentwater oxygen and nutrient exchanges along a depth gradient in the Baltic Sea. Mar Ecol Prog Ser 63:65-77

Krause H (1977) Produktionsbiologisch-ökologische Untersuchungen am Mikrophytobenthos im Zingster Strom der Darß-Zingster Boddenkette (südliche Ostsee). MS thesis, Universität Rostock

Kühl M, Lassen C, Jørgensen BB (1994) Light penetration and light intensity in sandy marine sediments measured with irradiance and scalar irradiance fibre-optic microprobes. 
Mar Ecol Prog Ser 105:139-148

Lange-Bertalot H (1998) A first ecological evaluation of the diatom flora in Central Europe, species diversity, selective human interactions and the need of habitat protection. Oceanol Stud 2:5-12

Lassen C, Ploug H, Jørgensen BB (1992) A fibre-optic scalar irradiance microsensor: application for spectral light measurements in sediments. FEMS Microbiol Ecol 86:247-254

Li Y, Gregory S (1974) Diffusion of ions in sea water and in deep-sea sediments. Geochim Cosmochim Acta 38: 703-714

Lozán JL, Kausch H (1998) Angewandte Statistik für Naturwissenschaftler. Parey, Berlin

MacIntyre HL, Cullen JJ (1996) Primary production by suspended and benthic microalgae in a turbid estuary: timescales of variability in San Antonio Bay, Texas. Mar Ecol Prog Ser 145:245-268

MacIntyre HL, Geider RJ, Miller DC (1996) Microphytobenthos: the ecological role of the 'Secret Garden' of unvegetated, shallow-water marine habitats. I. Distribution, abundance and primary production. Estuaries 19:186-201

Meyercordt J, Meyer-Reil LA (1999) Primary production of benthic microalgae in two shallow coastal lagoons of different trophic status in the southern Baltic Sea. Mar Ecol Prog Ser 178:179-191

Meyercordt J, Gerbersdorf S, Meyer-Reil LA (1999) Significance of pelagic and benthic primary production in two shallow coastal lagoons of different degrees of eutrophication in the southern Baltic Sea. Aquat Microb Ecol 20: 273-284

Meyer-Reil LA (1994) Microbial life in sedimenatry biofilms the challenge to microbial ecologists. Mar Ecol Prog Ser 112:303-311

Meyer-Reil LA, Neudörfer F (1998) Structure and function of photoheterotrophic biofilms along a gradient of eutrophication in a coastal inlet of the southern Baltic Sea. Proceedings of the Workshop on the 4th and 5th December 1997 at the UFZ Centre for Environmental Research Leipzig-Halle. In: Becker PM (ed) Microbiology of polluted aquatic ecosystems. UFZ-Bericht 10, Leipzig, p 199-200

Miller DC, Geider RJ, MacIntyre HL (1996) Microphytobenthos: the ecological role of the 'Secret Garden' of unvegetated, shallow-water marine habitats. II. Role in sediment stability and shallow-water food webs. Estuaries 19:202-212

Mills DK, Wilkinson M (1986) Photosynthesis and light in estuarine benthic microalgae. Bot Mar 29:125-129

Neudörfer F, Meyer-Reil LA (1998) Kleinräumige Bestimmung respiratorischer und photosynthetischer Prozesse mit Sauerstoffmikroelektroden in Sedimenten. In: Vereinigung für Allgemeine und Angewandte Mikrobiologie (VAAM) (eds) Mikrobiologische Charakterisierung aquatischer Sedimente, Methodensammlung. Oldenbourg Verlag, Wien, p 245-260

Nielsen LP, Christensen PB, Revsbech NP, Sørensen J (1990) Denitrification and photosynthesis in stream sediment studied with microsensor and whole-core techniques. Limnol Oceanogr 35:1135-1144

Oren A, Kühl M, Karsten U (1995) An endoevaporitic microbial mat within a gypsum crust: zonation of phototrophs, photopigments, and light penetration. Mar Ecol Prog Ser 51:151-159

Pankow H (1990) Ostsee-Algenflora. VEB Gustav Fischer, Jena

Pickney J, Zingmark RG (1991) Effects of tidal stage and sun angles on intertidal benthic microalgal productivity. Mar
Ecol Prog Ser 76:81-89

Pickney J, Zingmark RG (1993) Biomass and production of benthic microalgal communities in estuarine habitats. Estuaries 16:887-897

Plante-Cuny MR, Bodoy A (1987) Biomasse et production primaire du phytoplancton et du microphytobenthos de deux biotopes sableux (Golfe de Fos, France). Oceanol Acta 10: 223-237

Radach G, Berg J, Hagmeier E (1990) Long-term changes of the annual cycles of meteorological, hydrographic, nutrient and phytoplankton time-series at Helgoland and at LV Elbe 1 in the German Bight. Cont Shelf Res 10:305-328

Raine RCT (1983) The effect of nitrogen supply on the photosynthetic quotient of natural phytoplankton assemblages. Bot Mar 26:417-423

Rasmussen H, Jørgensen BB (1992) Microelectrode studies of seasonal oxygen uptake in a coastal sediment: role of molecular diffusion. Mar Ecol Prog Ser 81:289-303

Revsbech NP, Jørgensen BB (1983) Photosynthesis of benthic microflora measured with high spatial resolution by the oxygen microprofile method: capabilities and limitations of the method. Limnol Oceanogr 28:749-756

Revsbech NP, Jørgensen BB (1986) Microelectrodes: their use in microbial ecology. Adv Microb Ecol 9:293-353

Revsbech NP, Jørgensen BB, Brix O (1981) Primary production of microalgae in sediments measured by oxygen microprofile, $\mathrm{H}^{14} \mathrm{CO}_{3}$-fixation, and oxygen exchange methods. Limnol Oceanogr 26:717-730

Revsbech NP, Jørgensen BB, Blackburn TH, Cohen Y (1983) Microelectrode studies of the photosynthesis and $\mathrm{O}_{2}$, $\mathrm{H}_{2} \mathrm{~S}$ and $\mathrm{pH}$ profiles of a microbial mat. Limnol Oceanogr 28:1062-1074

Rieling T (1999) Remineralisation organischen Materials in Boddengewässern Mecklenburg-Vorpommerns unter besonderer Berücksichtigung der Bedeutung von Partikeln und Aggregaten. PhD dissertation, Universität Greifswald

Rieling $\mathrm{T}$, Gerbersdorf S, Stodian I, Black HJ, Dahlke S, Köster M, Meyercordt J, Meyer-Reil LA (2000) Benthic microbial decomposition of organic matter and nutrient fluxes at the sediment-water interface in a shallow coastal inlet of the southern Baltic Sea (Nordrügensche Bodden). In: Flemming BW, Delafontaine MT, Liebezeit G (eds) Muddy coast dynamics and resource management. Proc Mar Sci Vol 2. Elsevier Science BV, Amsterdam, p 175-184

Rizzo WM (1990) Nutrient exchange between the water column and a subtidal benthic microalgal community. Estuaries 13:219-226

Rizzo WM, Lackey GJ, Christian RR (1992) Significance of euphotic, subtidal sediments to oxygen and nutrient cycling in a temperate estuary. Mar Ecol Prog Ser 86:51-61

Robinson DH, Arrigo KR, Iturriaga R, Sullivan CW (1995) Microalgal light-harvesting in extreme low-light environments in McMurdo Sound, Antarctica. J Phycol 31:508-520

Sakshaug E, Bricaud A, Dandonneau Y, Falkowski PG and 5 others (1997) Parameters of photosynthesis: definitions, theory and interpretation of results. J Plankton Res 19: $1637-1670$

Schiewer U (1998) 30 years' eutrophication in shallow brackish waters-lessons to be learned. Hydrobiologia 363:73-79

Schlungbaum G, Baudler H, Nausch G (1994) Die Darss-Zingster Boddenkette-ein typisches Flachwasserästuar an der südlichen Ostseeküste. Rostock Meeresbiol Beitr 2: $5-26$

Schnese W (1973) Untersuchungen zur Produktionsbiologie des Greifswalder Boddens (südliche Ostsee). I. Die Hydro- 
graphie: Salzgehalt, Sauerstoffgehalt, Temperatur und Sestongehalt. Wiss Z Univ Rostock Math-Naturwiss Reihe 22:629-639

Schubert H, Sagert S, Forster RM (2001) Evaluation of the different levels of variability in the underwater light field of a shallow estuary. Helgoländer Wiss Meeresunters 55: $12-22$

Shaffer GP, Onuf CP (1983) An analysis of factors influencing the primary production of the benthic microflora in a southern California lagoon. Neth J Sea Res 17:126-144

Sommer U (1994) Planktologie. Springer-Verlag, Berlin

Sommer U (1998) Biologische Meereskunde. Springer-Verlag, Berlin

Stodian I, Gerbersdorf S, Rieling T, Black HJ, Köster M, MeyerReil LA (2000) Geochemical investigations of iron and manganese in coastal sediments of the southern Baltic Sea. In: Flemming BW, Delafontaine MT, Liebezeit G (eds) Muddy coasts dynamics and resource management. Proc Mar Sci, Vol 2. Elsevier Science BV, Amsterdam, p 149-160

Sundbäck K, Snoeijs P (1991) Effects of nutrient enrichment on microalgal community composition in a coastal shallow-water sediment system: an experimental study. Bot Mar 34:341-358

Sundbäck K, Enoksson V, Granéli W, Pettersson K (1991) Influence of sublittoral microphytobenthos on the oxygen and nutrient flux between sediment and water: a laboratory continuous-flow study. Mar Ecol Prog Ser 74:263-279

Täuscher L (1976) Ökologische Untersuchungen am Mikrophytobenthos im Zingster Strom der Darß-Zingster Boddenkette (südliche Ostsee). MS thesis, Universität Rostock

Teubner J (1989) Quantitative und qualitative Erfassung submerser Makrophyten 1986/87-Luftbildanalysen. MS thesis, Universität Rostock

Ullman WJ, Aller RC (1982) Diffusion coefficients in near-

Editorial responsibility: Kevin Carman,

Baton Rouge, Louisiana, USA shore marine sediments. Limnol Oceanogr 27:552-556

Underwood GJC, Boulcott M, Raines CA, Waldron K (2004) Environmental effects on exopolymer production by marine benthic diatoms: dynamics, changes in composition, and pathways of production. J Phycol 40:293-304

Walsby AE (1997) Numerical integration of phytoplankton photosynthesis through time and depth in a water column. New Phytol 136:189-209

Wasmund N (1986) Ecology and bioproduction in the microphytobenthos of the chain of shallow inlets (Boddens) south of the Darss-Zingst Peninsula (Southern Baltic Sea). Int Rev Gesamten Hydrobiol 71:153-178

Wasmund N (1990) Characteristics of phytoplankton in brackish waters of different trophic levels. Limnologica 20: 47-51

Wasmund N, Kell V (1991) Characterization of brackish coastal waters of different trophic levels by means of phytoplankton biomass and primary production. Int Rev Gesamten Hydrobiol 76:361-370

Wasmund N, Schiewer U (1994) Überblick zur Ökologie und Produktionsbiologie des Phytoplanktons der Darß-Zingster Boddenkette (südliche Ostsee). Rostock Meeresbiol Beitr 2:41-60

Webb WL, Newton M, Starr D (1974) Carbon dioxide exchange of Alnus rubra: a mathematical model. Oecologia 17:281-291

Whitney DE, Darley WM (1983) Effect of light intensity upon salt marsh benthic microalgal photosynthesis. Mar Biol 75: $249-252$

Wiltshire KH (1992) The influence of microphytobenthos on oxygen and nutrient fluxes between eulittoral sediments and associated water phases in the Elbe Estuary. In: Colombo G, Ferrari I, Ceccherelli VU, Rossi R (eds) Proc 25th Eur Mar Biol Symp. Olsen \& Olsen, Fredensborg, p 63-70

Submitted: January 16, 2004; Accepted: August 7, 2005

Proofs received from author(s): November 4, 2005 